る意得古に級うスしる。大

者的の社が社論とのて。が階今 に分多会い会の寸階いこみ級日 と類寒学を階否る級るのて論階 っを等の混層定立理こ場、を級

ても々階乱のに場論と合よも研

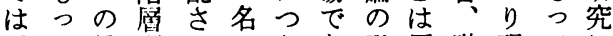
、量理せでなあ発周階現てに むし的論て呼がり展知級実はた して指はきばる、との概に分ず ろは標多たれいいしこ念そ析さ 社に彩よるわまて劣くしわ 社会むでうとゆ—、がめしつる 問 貧

題 の あ り

困

研 究 に 会のとあにこるつ階らぐたく者 政つうる思ろ社は級でっ分せに 策構くがわか会、内呙あて析なと 学造上、れら学氏部る三のいつ の的下つる、のもの。う用社て 分把のま。や階育層以の具会最

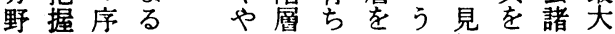
で列と理を副ま解見現の 発はにこす論ち次でが出象課 展不す万机でが的も互すの題 せ可ぎは代あい階なにこ存は し能す威概るな級くいと在 めで、信念。がと一れにすマ らあその 上両らしつがおるル れるう程の者、てはたか事ク たとし度明は二見、くれ実石 考たや確と大出ル対てにの か

階

層

の

概

労え等所な正階そク立心か三

低めそをあ究出たる施わして層㗢 生てれ二るのこす社。義らて改另 活社が身。過この会こ分せのめの型 費会体に資程でで層の析て出て理等 や問制担本で取あな世展稼子論論 貧題のう主明上るい率に開型れのや 困化維と義確げがしをおしなる方 階し持こ社华る、は単いたいまに生 層研にろ会さの別階位てもしで の究とのに机はの層と、の半もよ研 研のっ労おる、機と专労で農なり究 究対て働けに同会いる働あ半く多。

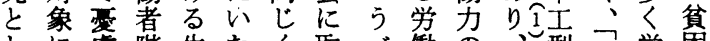
しに庿階生たく取べ㗢の、型学学困

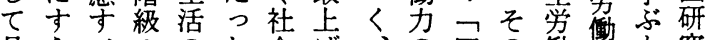
具えへののた会げ、の四の衝堵も究 体らき生研子政たこ編つ源力型のの 化れ問活究国策のこ制の流を型を過 寸る題問は民学でにこ型は日論も程 るとに題、諸のこ階そ出山本とつで ろまとこ階分こ野で分は編思盛社はてい具 か発て体には析日と太会特る化 ら展出制の属ふの本し郎政殊。さ 生た登む理しれな基の論なな策貴尔た 活とるつにがい凤的実えつ特的 研き。主つら視をら日質な 究にと要い生角子れ本と形 ははく矛て活をまて資か態 最じに盾で研見えい本かと

鎌

田 旧と た 姓

国部子 
同階で流く会 I考る階域わに治論し究てて貧ても資 時㾪、に刻政のえ階級最とりと郎とたへき困くま本貧 にの必ま印策影て層の近限あっ社䄈たた階るた主箱 今理要でさ学響みの下こ界いて江会。云。局。現義は

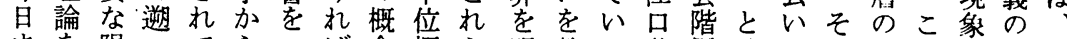
まを限ってらつば念概ら明整か英層くか据れを独初 で階りてい出よ日と念二確理な二論にえは出と全占期 の級に論た発く本あと連にしる氏で社て家へ対体段の わ研拄理としうのるしのし、意らあ会も計、応社階段 た究いのしてけ生其て紧た社味のり学よ研さし全で階 くのて形ていて活通意績い会を諸、をく究吃て的はで し中子成決る打研性図にと学も業前学、加に日視広は のにれ過したり、究をさ接いのっ績者ふこら相本野く人 任位る程てめ、、はも妃しう分てに老者こ生対のに国品 事置こを不元つてての野い代籠にで活的生拉民の にうと追思彼方様のい感がでた表山とは菉過活い大あ 対けにう議ら大にでるずね階のさ京っそ造・剩研て衆る しるしこでの河エはにるら級かせ、てうの、人究構を部 てととは思内ンなもこい研、て中意し研品を造と分 もこ焦はな想氏ゲいかとで究す紹鉢義た究、の初的らを

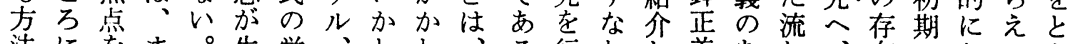
法にをま。生労、とわ行わし美あれ、在のとてら 論合日たこ活衝ブいら国。なち、氏るにさ形最らいえ

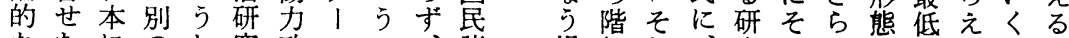
なたにのし究政スこ、諸場級れ、究っにへ生るのに 反いお課たの策、と社階合研ら後はて階と活必です

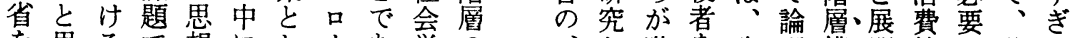
を思るで想にし、あ学の 加ら国あ的いてンうで概 え。民るなろのトた用念 たと諸の源こ社リ。い忍

之階索生理構・開算に貧な 分の級氏活を造、せ定迫困い 担か研原構展の、らから研が 領か究正造開研れられ究

機れのも家わか।

能資らつの計せに労大け を本れエが分て 活働原

分制たンあ析読況者社生 離生の帝でり、のん家荋活 しのあ係瞠角みいの題造 め、支る。数自にるし生研論 以はにさ彼と費究展 後自あるものい先開 貨給 らを、もわが高 幣経わ方わっれ紹野 を済さながてて介岩 媒を动い国いいさ严 介破るのにたるれ郎

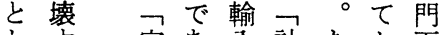

し家あ入計たか下

てる計るさ量だらに

両こ費がれ社工、よ

者之自、た会ンわつ

のに のと理学占ゲがて

循よ構を論じル国エ

環っ造かをのののン

がて道く構他家ゲ

行生ともる想の計ル

な産し日かに著研の

わと本にし書究

れ消とに越てをはべ

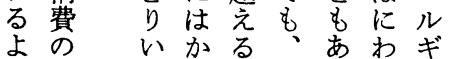

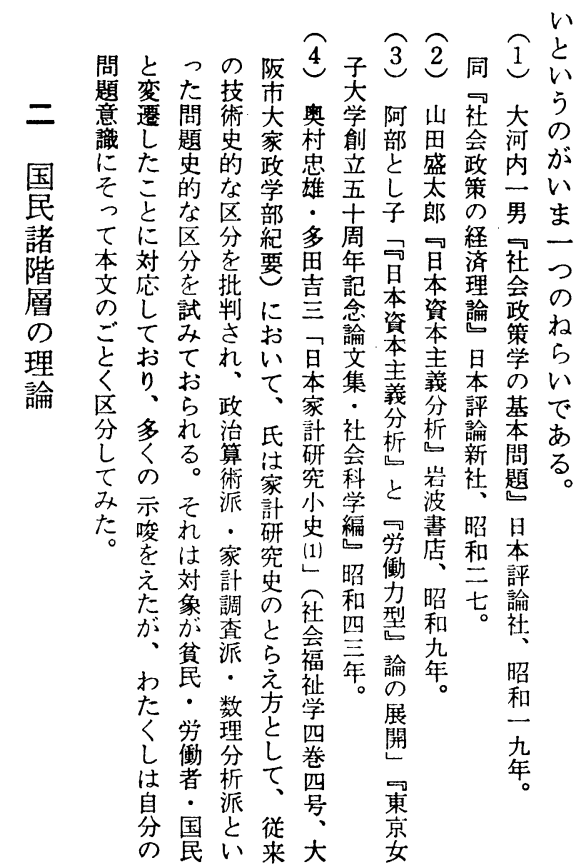


て題せあれは造は推子あと政国にを川といいのう 放とらるる、がめ满国げど策でこ寄かはいみこえ再に 置なれ労き全存、造此、論はの梊たあうすのに生な さりた㗢ら生在一を生見りの早生すちる観る場エ産っ れ、か者い萿尔旦萿事理中く産るうて点の合方構た て (2)ら生が時る三らのな論ではととくいかでのゲ造 き生で活あ間こ四え構奏的そ永消こつどらは生ルを労

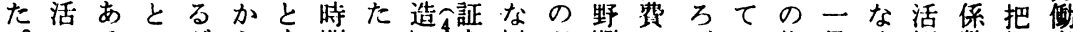

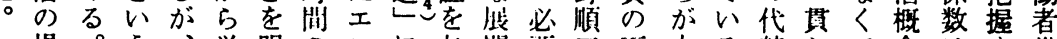
し場。 5 、労明のンに年開要三画大る替して念は守世 かはこもこ㗢ら生ゲおえは性氏過きこ川た、画る侕 し貨ののれ時か活ルいらみがの程かと補生生、期たの (1)金たがは間に時にてれら論生をつ它完活産生的め家 とのめ出工をさ閆な、たれじ活生た發関の要産なの計 (2)使 (1) 来場されにら家のなら研活と兒係論素とい可收 は用労た制したをつ計はかれ究的心ししを理と切み視支 一が㗢こエひ。代て支籠つてての流えたもをしりを的の 日行のと業いす替こ出山だは中れよ点ち展てはをで費 三わ場にがたな補れ構京。いでとうでな開のなる計目 四れでよ始残わ充を遮氏こた、し。がし労さて量別 時るはつまりち関労をでれがまてのらよ働れい可構 間だ労てっの従係動指あを、た把ち全 5 力たた能成 のけ衔、て時来の著標あ専単大握 中の力労以間生成のと乞閏な河守 に個の働来に活立生した領る内る 連人使と時対活す活て氏域問一観 連的角生間しとる時労氏と題男点

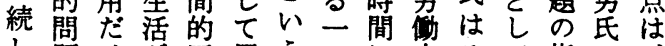
し題けが区用うつに力そて指の てとが分分い概のあ再のと摘社わ おし問離のら念構て生著りに会が

の体との消のなは 生とし消费で指い 活した費生あ標わ 構て点と活るでば 造 — そ 論つ各の私り做 のの家 再生、务 発構計生活售 展造費産を机品

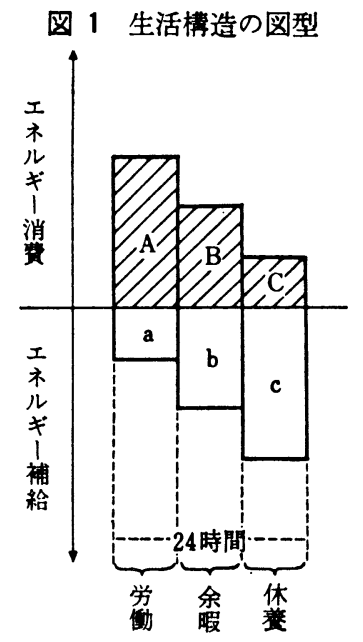

（注4の文殸 p. 81 のより蛙载） 三つの基本状管

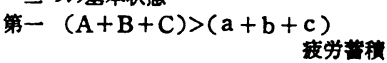

第二 $(A+B+C)=(a+b+c)$ 理兴的にのみある

第三 $(A+B+C)<(a+b+c)$

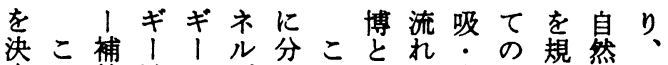
定の給消はギかのしに食人定で両 寸 $\mathrm{A}$ 量费基 机よてそ事間守あ者 る、で量碟のるうのっ・のるるの の B あで代消生な発た睡立と。合 は、るあ謝费活生想工眠場い生計 C 。りの是時活市加う産こ 生の、意示間をうルのら事がそ 活三下でしの全かギ結見実消二 主向あ。楎体が、倮直は费日 体の矢乃休造とわ循とさ容をな と消印う美をしれ環しれ易規の し费に時次てて热てるに定で て 示A間のと興主のベ理导あ の、さA、によら味軸作き解るっ 人 a れ、おうえ深で業でさ閶て 間、た、、にるいあ古あれ倸対

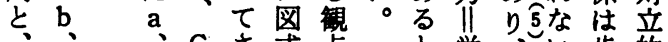
Cさ式点 と労、以肯的 生 c b、の充化吕主扸生が定に 活の、合消さら、張力理、取 循三 c 計費れ、さの理むれり 環つのがさた勾労 れ発的して报 要の 合一れ倾 る揮機ろむわ

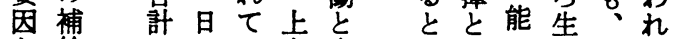
はのい向余こいの活消る エ総る矢服ろう発主費こ

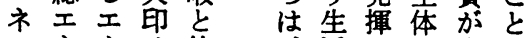
ルネネは休活委生は ギルルエ㟤医の呼し産不 


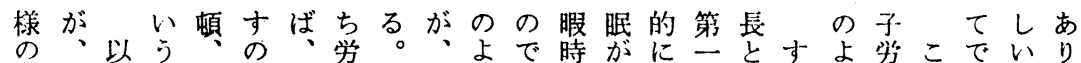
調つ上悪不でそ働つこ実閒決余にななう㗢うは状、 香いは循明あののま记に際がま暇労”わな者しな態そ をで肉環朗る陰延りに、に短る時衝てち結兰たくにこ

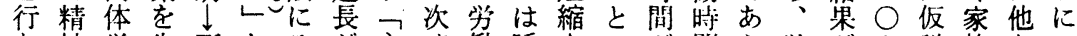
な神労生不とそが主ぐ働睡さいが間ら学が必説族な三 心的働む健。の学人要者眠机え支老働え名に全らう 、労にと全そ労務の因生時るる出支机時らにも体なの 労㗢従いなし務者学と活閶か。せ出る間机対ととい基 㿥從事う子て者の衝しのがにっらしたのたしうしが本

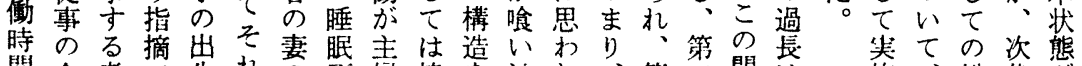

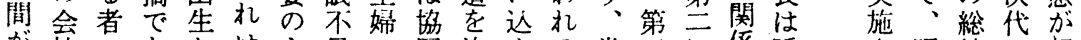
が社のあとはよ足の同決まる常管に係睡さ昭結の想

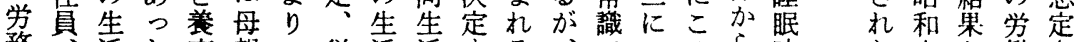
務、活た育親一従活活守る、正このら時た十と衝さ 者銀構。」の層っ時のると社考の学生間実六し力机 に行造次不息て間如第い会え余働生考熊年て再る 比員と代健睡過の何一う的机层時活延調京成生。 し の康眠労配川要こにば時間櫣非查浜立産こ

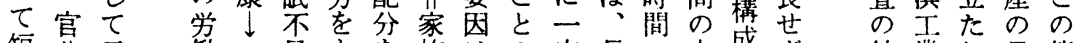
短公示㗢二足もを族はの定長の大威ず結業权見第 い茰さ力家とたもの労発時時大小元し果地ば地 の等れのの過ら規有㗢見間間小に年て茦なか基 でにた縮不労す定無にでが労に対晧余にののらら本 一つも尔健と\&し唯他あ要働相応閆、製な個状 日いの 再康をの ‘あなっ求に反し的時お銅い人熊 のてで生とをで

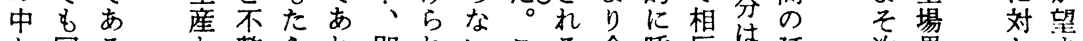
か同ると整られ即れいこる余睡反は延次男し市

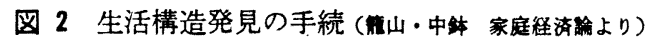

A. エンゲル線の理論值

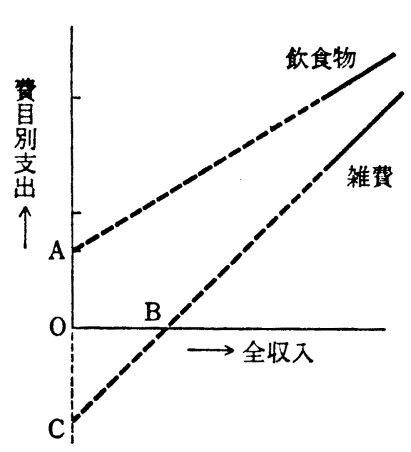

収入がゼロになっても飲食物

費はゼロにならないで，Aで とどまる。
B. 枠による涪曲

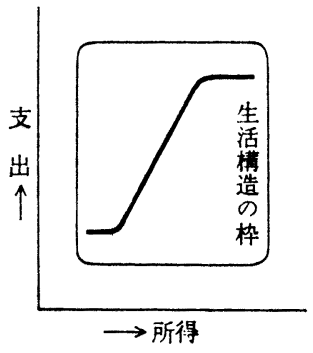

上・下にみられる湾曲は，

今までの枠に対する抵抗

による。
C. 枠ごとに示される非連続

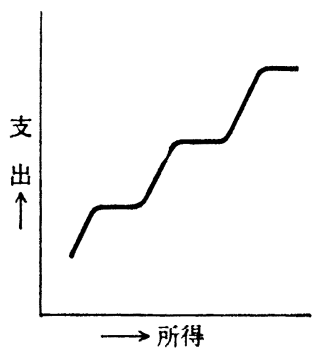

エンゲル線は枠ごとに湾曲 を示ナ。この断周が生活灀 造の存在を眐明る。 


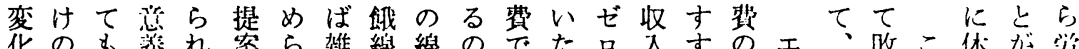

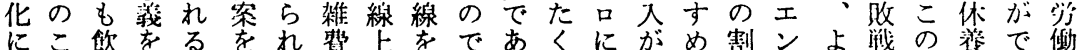

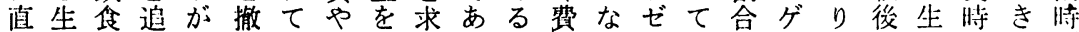

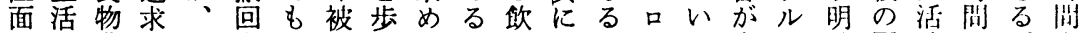
寸以费卞こさそ服いて。湌相前にく多の確国時の。老 るががるこ机の茄た最森物当になとく法に比间喰そ山 と行ゼこでた想をであ低田費すぜつ図を則打生をいれし な口と土呅さの生優はる口て2 占にち活指込故余 たわににン籠ゼえ窮活兰生雑にものめよ出窮蓝みに服

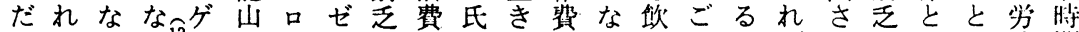

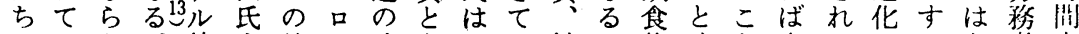
にいな。線も線に時考こい被こ物くと家るのるな者を はたい氏がこには代えこる服と䩀、に部こ時二らの文 そかとの直れ平なにるか限費には費なのと代つな場出 のらい言線と行ら害こらりをなゼ目っ支ににのい合し

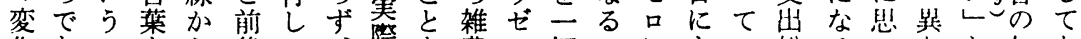
化あこをら後て、際を費口切によい総るいなと如な にると借曲し禁各に提罢に使図はつる額。がついくお

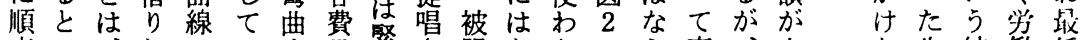

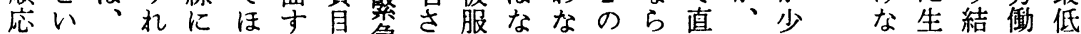

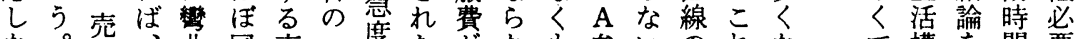

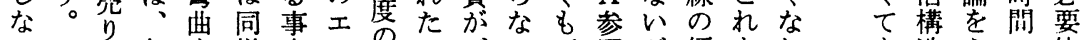
いつ喰收守様害ンのこぜい死照が傾をれ も造えの休

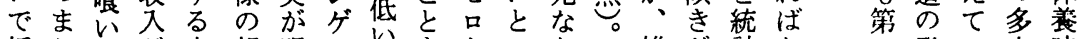
抵りのが点報明ル費もといな雑が計な 三発い少時 抗生生ゼ拜的ら線費あなういつ費ち学る 寸活挐口極索かは貝るるこがまはが的程実は。延を る驾に资しときたが10とと、り、収うに飲証、長残

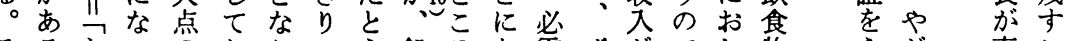
そるたっの拉つえ慨らな需ぜがでし物えが直こ

に異社に連つなで険えこ帯この主い共びい有 2 し 寸な会遭続か構さあ等ばう員ろ地観たでに、をののて ぎり階遇が存造きる々家しので位価つははそし生 B 一 な川層守み在をの族た意固值た生かの毠参定 い階とるらしもエ を制世識有産なも活ら抵で構照の

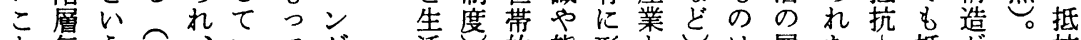

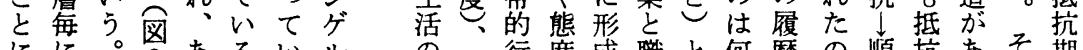
にに。の社行度成職と何歴の順抗あそ期 な水しのる。た線枠至為過さ業社かにが応すりれ間 ろ準たC類こかに租会㝸過れ会、よ中のる、はを うかが参型れら禁年諸循去る物経そつ鉢期かそなお ちっ妱吕をで曲し設環生と価済れて正間られぜい がて照ら構あ川

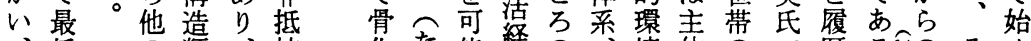
、低この類、抗化た能経の、境体ので歴る画のそめ 一生の類型こ㤎さとに験、地要的生あ期。脱れて

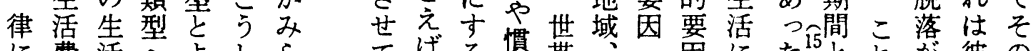
ひ費活とふふした れ か生造移な生たる給めと家入会遺有方易が华 れ活を行ら活の製のい族な会伝の性にそに

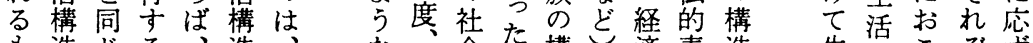
も造じる造、な、会た構し済素造生のこぞず

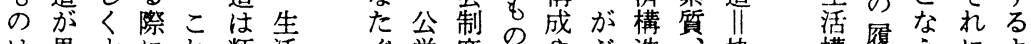

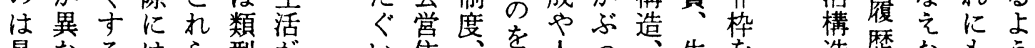

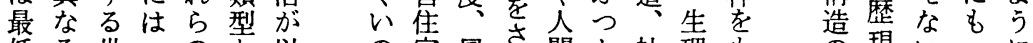
低る世二の立以宅風さ間か社理も琴いるに 再に带定間し上卡習し関り会的た 理象でてな 生つ集のにて市の社年係合経欲せ 論壳いる

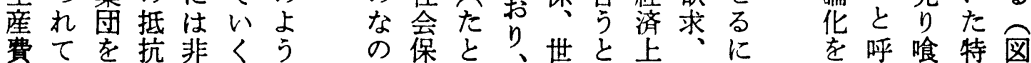




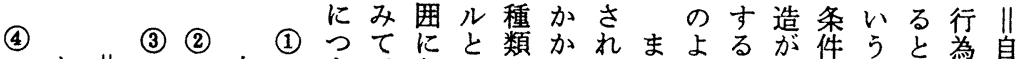

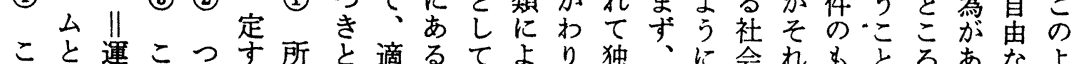

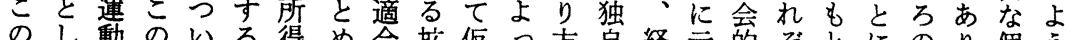
洗て坛仮っ方自経示的ぞとにのり個う 則の履デごこ格て範が説てにの済さ集れでな生、人に 性法磨と茬い囲り的所よシ社机団対一り活生の与. 性法框ルれか、くに得っス会るを応定、の活主え

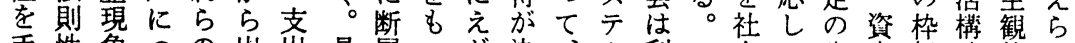
手性象つの出出具層つが決、台利会て生本組造的れ ががのいう発内体がのき定つで潤階存産のつと判た 加認存てちし、訳的みで出さま自追層在能要具は断社

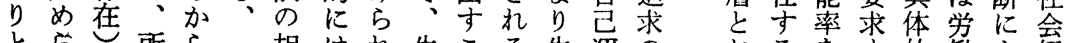

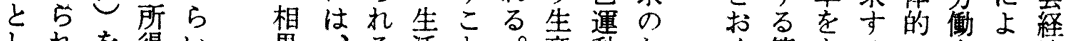
しれを得い異、る活と。産動たく筈もるに力っ済 てる観やく構がそ手をめ段告っいは再て的 そか察㿥つ生 う造でこ段行のであたく家生選環

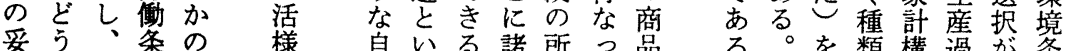
案古いる諸所っ品る。類構過が条

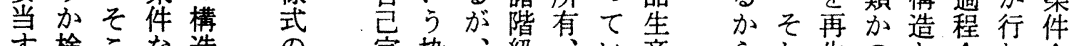
す検こな造の完枠、級、心産らし生のと京わ A

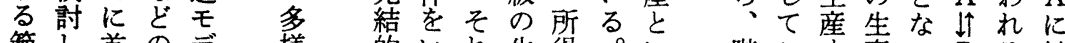

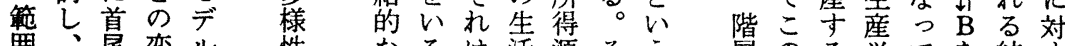
囲、尾変ル 性なろ活源そう層のる労てを結す

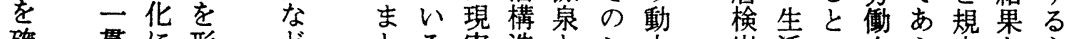

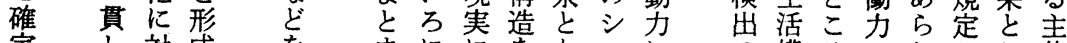

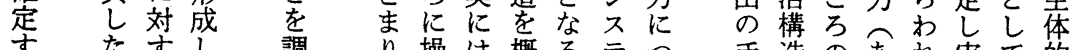
夺たすし 調り操は概るテう手造のあれ奏て的 る シる、查齐作適念労么き続を生るる現、条

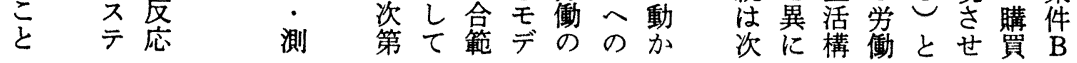

すに究に活外心俞本もう定や違ののい支であ論こと よっとっ次象的け的がにた度なきかたのろ種るううに うてった元がシら商、還がいさわ距費うのよしわよ な有てとで社 スれ品測元も習もにり離目。労うてけっ 階意意しあ会テて生定さし慣のよかと別そ衝でとでて 層味味てら問么产可れれ等がった差構し者ありあ

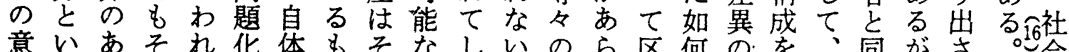

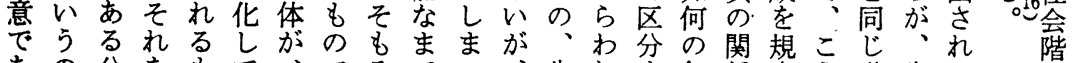
あの分をむてこでそでっ、生れ专叙倸定う階生る 層

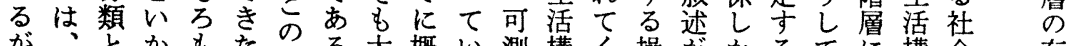
が、とかもた社る大概い測構く操がかるてに構会存 そ社はようろの社。量念る。性造る作目存所く属造階在

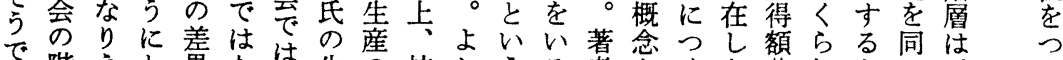

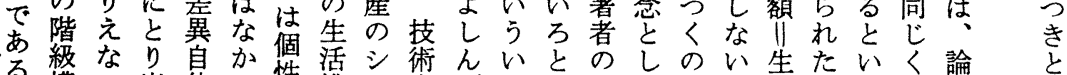

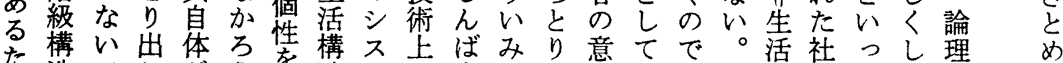

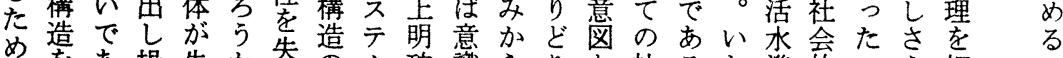
に老操失か、失の公確識らりと社るた隻的こえ押 は担ろ作わ。い中を化結にし会がるが集と导し はううしれしつ核もさ態果染て学、とよ団もれす 階二。てつたつにちれ度的めはの結こり相現ばす

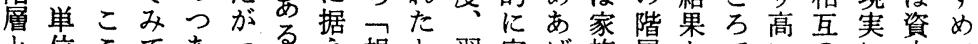
と位こてあっる規と䏨家げ族層とでいのに本て 階とに\&るて台ら格し慣計るのとし経か間は家い 層し階、し、扎化てと支指生ほて済低に起のく

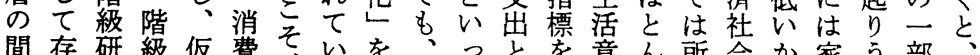
間存研級仮費そいを、っと意ん所会か家う部、 に在究研り生疎る運資たい想識ど得会と計るも極 


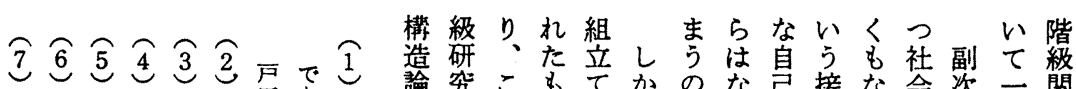

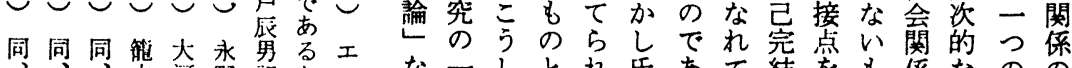
山河野訳かルな二しと机氏あて結をも係なのの 一一五京内順马、ンい環たみたのる相的ものに階構副 ㅈ.. 分可造劳はスしと批る望一。対なっで他級造次 项頁至国䍚国働た! 忙判な体連的社てあな関に的

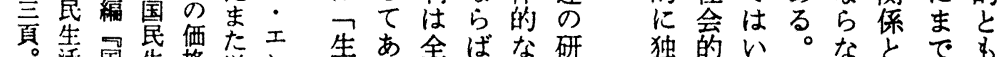
活国星格た峃䇭あ全ばな研独的い。なとでも

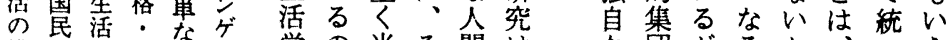

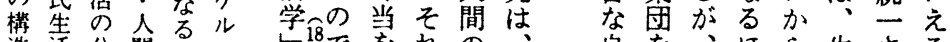

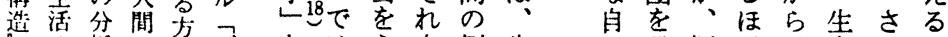
の析の法テとはえ自侧生学概ど、産れ関

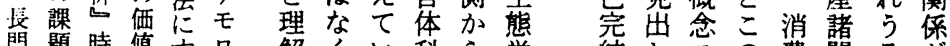

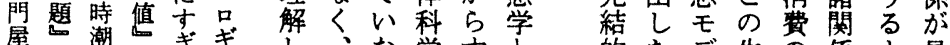
屋潮品ぎし、な学すと的たデ生の俰よ見

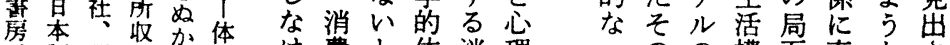
呯昭尔采け費と体消理可の構面直なさ 昭論和栗問悉れ生心亲費的

和社一田題及ば活えを生な

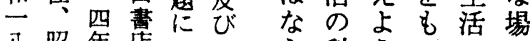

公昭年。店つつら科うつの年

作和。吸心統な学。たシ理

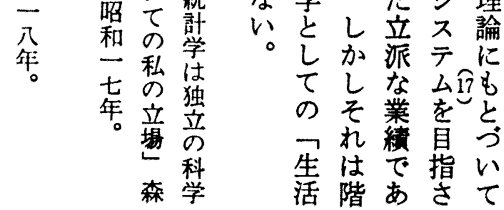

階瞬枠造か接単れ

層間を論らか位

しに操ははかでそ

のお作、本わなれ

地いし労来るけが

位てて㑬的面れ社

に、相力ににば会

転階対の出おな的

落級的再ていら過

乙概に生くてな程

て念独産る成いに

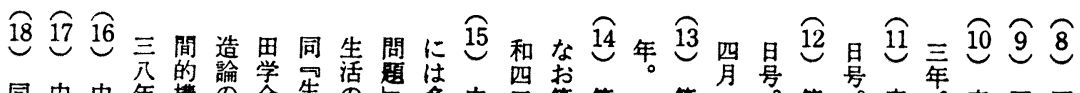

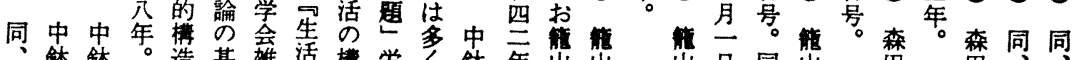

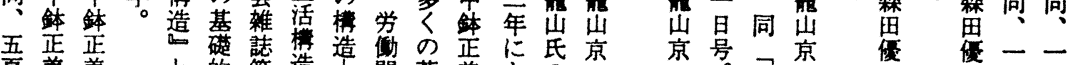

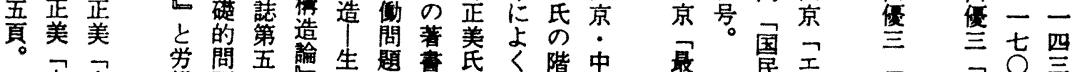

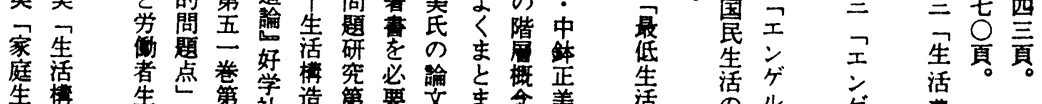

生椿告第学造第要要念美

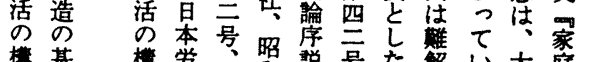

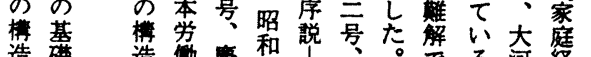

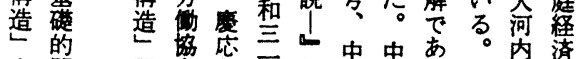

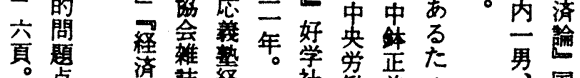

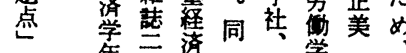

二 年西学社照学生生筫至

頁 7 量会会和等活活就

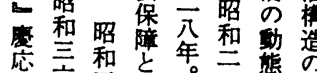

義雍年和点

垫年言会年们

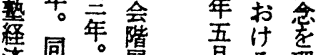

学同管

会劳素理

昭の活 蹠

和人榜三

月る 理

同堆蟹

家䡩た

家照

生
活
寡
最
集
告
産
费

活光兰

弿法留法

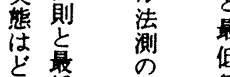

芌最䇙停隽

な生步金

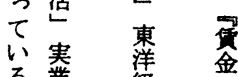

労る業経金

倠唯㝵落研

䒠

夆

業昭昭 洋

年星和和程

吾号

照年 年 新

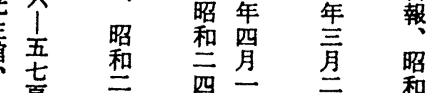

昭頁五票五 豆 和 
ら貨れも未産た本合名充彼よ間のど成えええ 金ての成費るしうこで足はりの中に彼しいらな生曰 社がいで年と生に賃のあさ的魀がてまれか活 会支る3 、期し産対金、るれこき最せ消み彼るっ構社 の払。当のて費置がよ。るれ消一もら費るの聕会 生わこ時養算をさ支り 産机方明青出本机払よ にてしら.し人るわき とこてか教た自息机 己算に充算躬な費 て、出さ費生の的け男 も順されと涯原資れ実 当れた、に価本ば現 階なた栄老わ償しなさ 級労人養年た却 ||られ 関 働間学期る費高なる 係力ののの生と価いた の再二成扶産家な。め 安生費果養費族機エに 定産角を費亡械ンは。 の唯価子とは含とゲ、 た行值まを含労たて余閏 にわしえ含労たては間 も科き期々ら人衝 のるか学わのの文間力 ぞのな的めみ労文市 までうにてな働生価 しあに算詳ら力涯物 值 いる足定細ず再に的に こかるさな、生わ資見 程を費切発机のと諸ン理論階 度福のが達、研つ論ゲ用が集 祉行消が生究ぎ文ルはす諭 にのわ費お涯にののの、ぐの 求最れのくのつよ中問これ展 め高るたれ課少うか題のた開 て状状めて題年にら意理着 態態にいと時な、識論想 かとを行るす代る課ののに のお人わかるに。題中形も エき間れらに樑にに成か ン、社る2といいと見にか ゲそ会しいた感っ出さわ ルののとうつ銘てすいら 係測到考理た定必こしず、 数定達え由のう要とで、 導指べこみ、て 部でい級 き標きとで経之分き影研 出直には済の虜とる。響究 た生だるくと势方系 こ活と欲考之統な 出っ譜

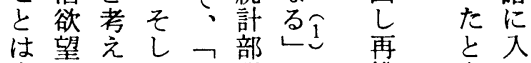
有等たて人归ほ構考り

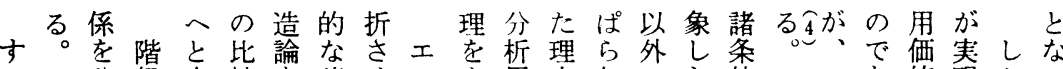
で分級向較を諸せンを用由収にた件こエあ值現かの に析関わに展関るゲた具は入な消のうンるしさしで マし係なと開係因ルなにこ階か費一しゲか実れ人あ ルよのかどさを子がかすこ層っ研切てルら現な間っ

クう中っまれあと、つぎにでた究が現は、のけのた

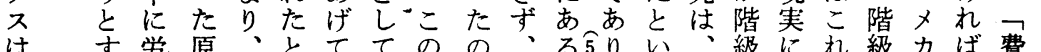

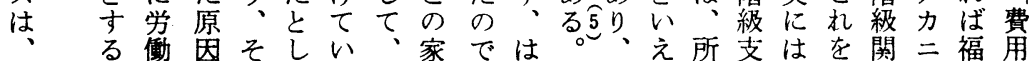
資試者をうてる家計あじそ収る得配賃係ズ祉価 本みの部族構るめれ入。のの金収のムが值 論は生エた、分及造 に、活ン差収をびと おむををゲ異入発こ所 いし位ルを階展れ得 て ろ置の生層せを額 相貧亏方ず間しとと

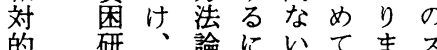
過究各のいしくく 剩の階中た職籠職レ 人過層につ業山業। 口程相見た階、的卜 がで互出階層中。な 資生の守級間鉢 社 対 本間の関の氏会応 蓄たので係生が的関 積と社あの活生・係 の い会る把構活地を 過え関。握造構域届

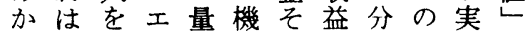
ら家規ンか構の価析中現が 階計定ゲらの他值にでさい 級支守ル入中のし寸、れか 関出るがりで労の寸現たに 係のと分、決衝領ま実こ厳 の費必析家定諸域ねのと密 分目うの計さ条でば福にに 析別い中支机件あな祉は計 へ構みで出てのるら状な算 と成で用のくみとな態らさ 発をのい費るなしいはなれ 展比職た目とらてと決いよ す較業階別いず切とめ。う る守階層構う、りこらつと

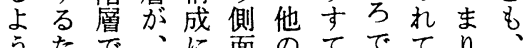
うたで、に面のででりり 生でる 論のつっる捨活いるる費れ 


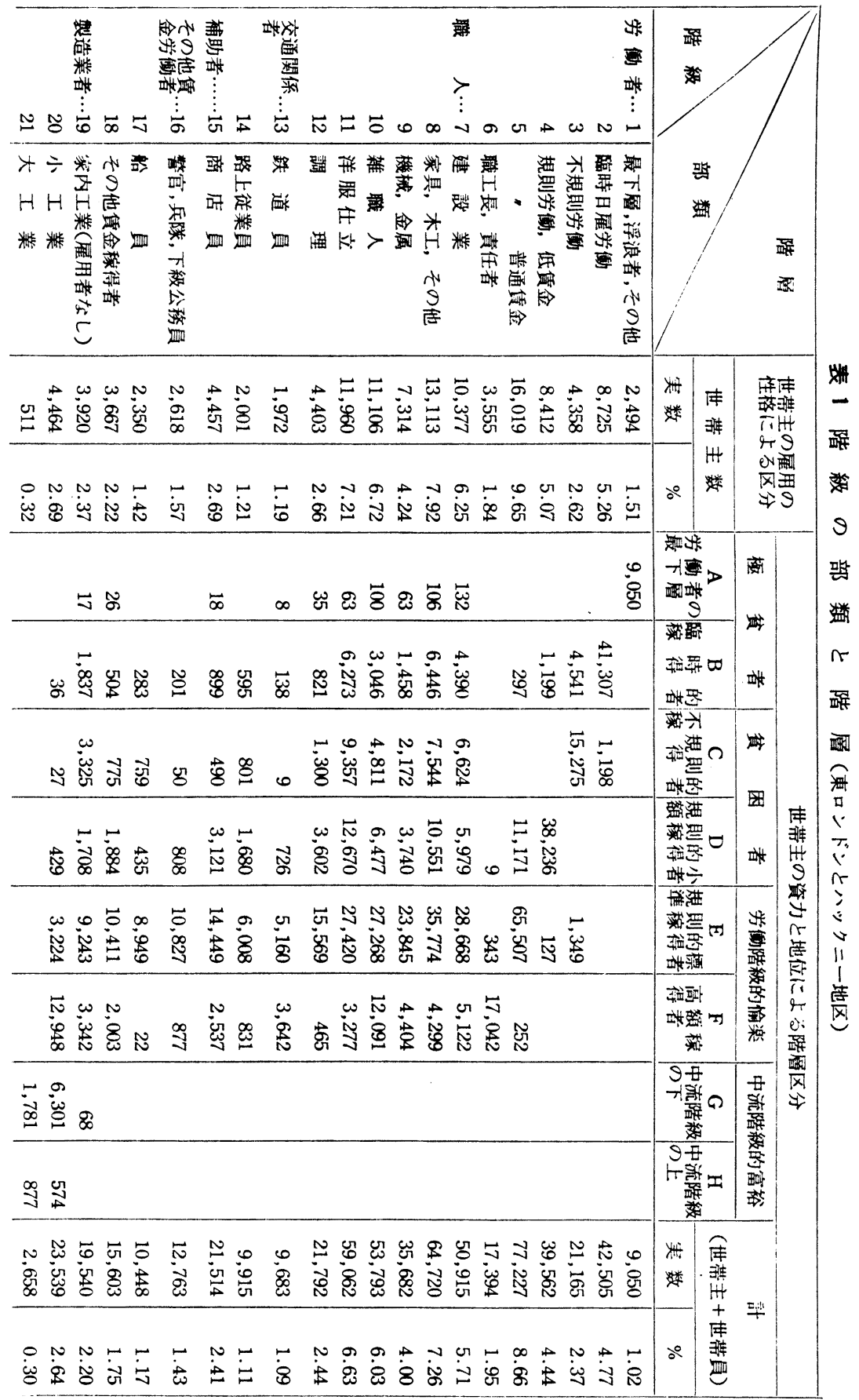




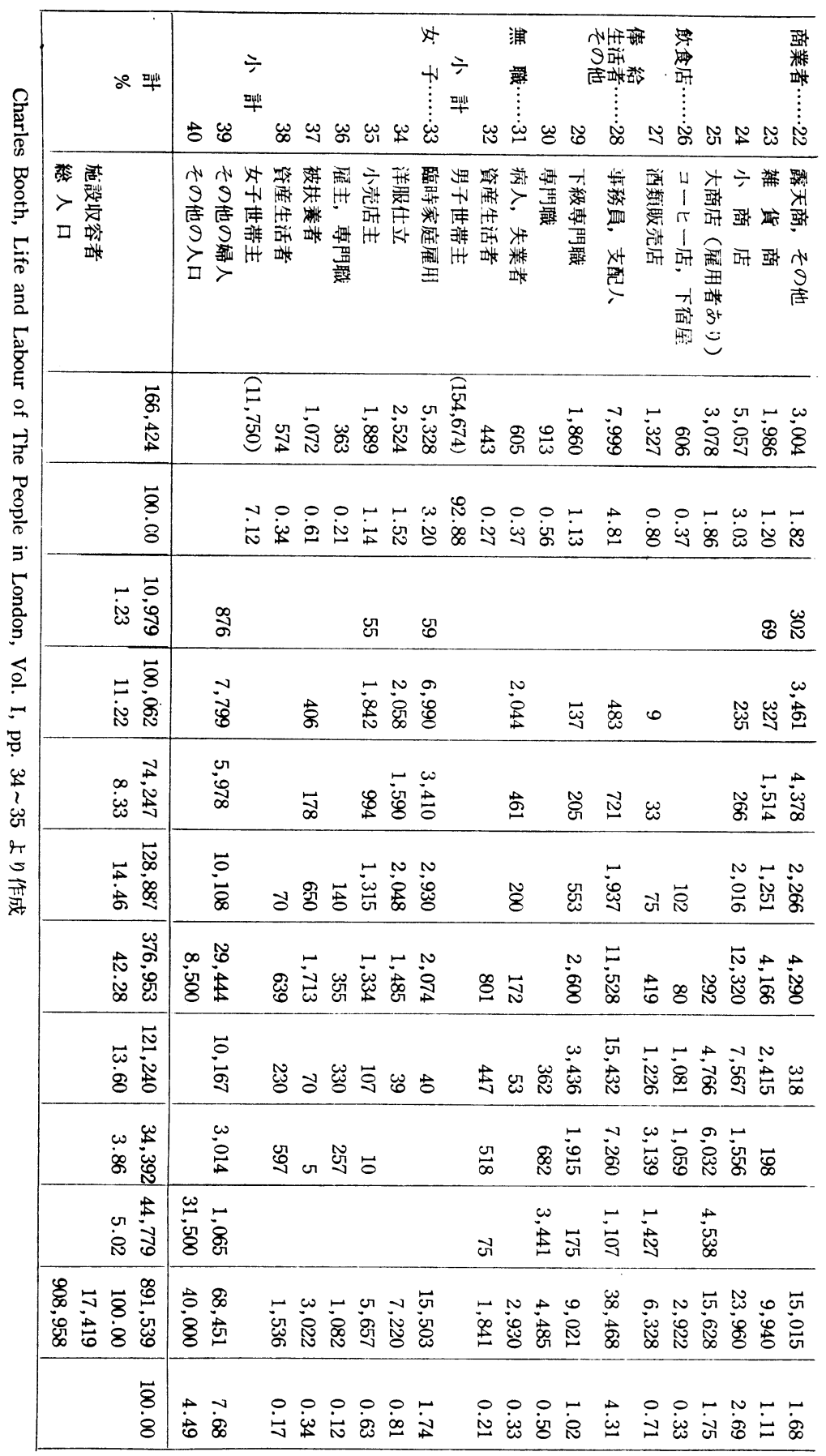


はあよ子体因階な㤵働池もい分救り具俑のらそ程

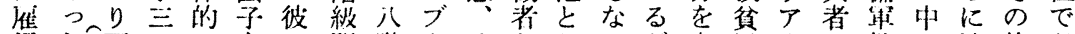

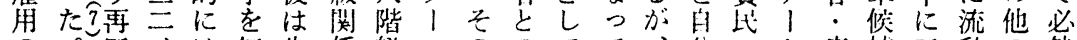

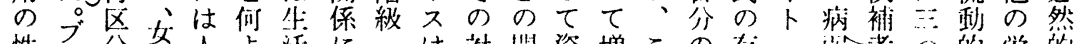

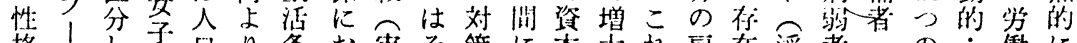

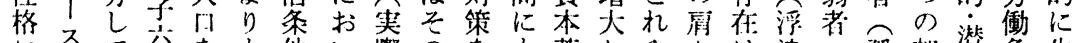

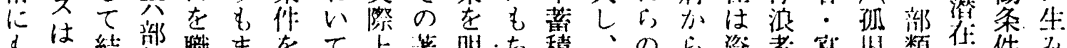

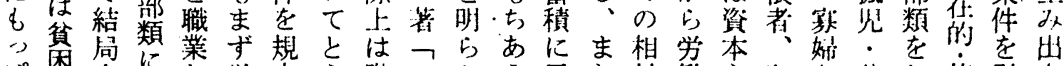

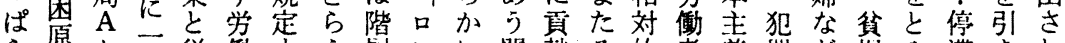

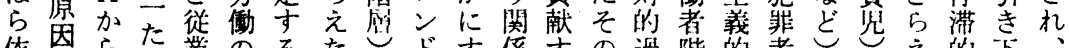

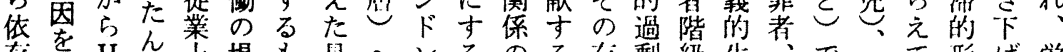

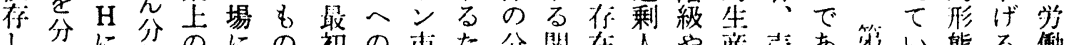
乙析に類のにの初の甫た分閔在人や坚莣あ第い態る働

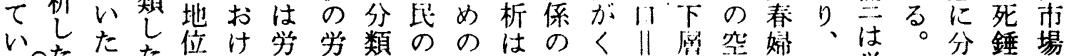

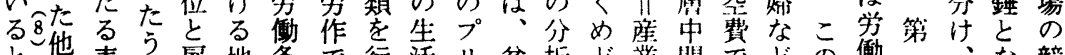

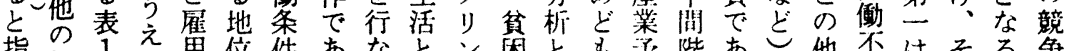
指処 1 え用位件あなとン困とも予階あこ他不はそる争

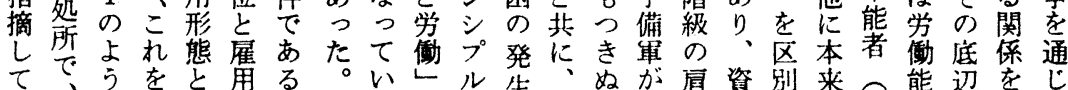
いcなをと用る ると八ら組性しがお热恩争貸本転はてル落者位し現 よ D 階し合格て次因を金蓄嫁こいン者置た役 うク劂むせに、貧てた之通労䨝すのるペ・第すが労

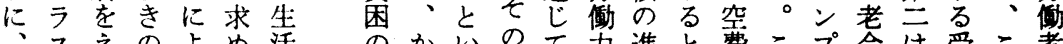
スえのよめ活のかいのて集と費こプ令は受こ者 儥のた程ったの問のえ存現の行の金者産救れの 金貧の度て。規題有る6在役貯にべ大らレ・業貧を偭 労困でに男具定名名形労水とて部受夕不予氐さ金

作営者が江た只入出す分にと困がもすと㗢

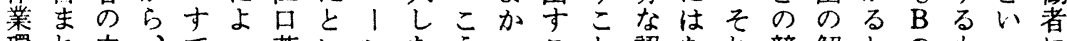
環れ中、でっ英いンたうっこと認ち机競解とのをるに 境るで勤にて二わト点したとに識がは争決い競のてと そ諸王労大よ氏ねり年だたでな゙い階かがう争でよつ の条延生河りにば、帛、不であるなな級ら救、があくて 他件工活内精 うなとの十あり。かい関除貧労 C る 間 のでの一密けらちち分る、すっが係去法㗢と。D歇 要あ種男化つながにな。競なた全の拉の市 Dし以的 素高る類氏さがいっ階把争わた部貫る拡場のた下な が温か|はれれ。て層握関ちめで徽こ張に足がの労

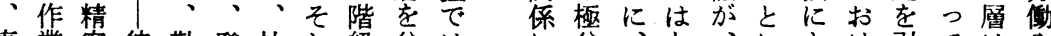

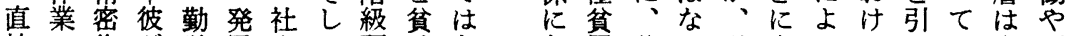

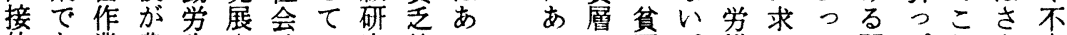
的あ業農生さ政こ究線っるに困。㗢めて關ぱれき安 にるに民活せ策のにかて 他救のに者ら極俰りらの定 そか従でがら学観凟らも算解も階れ貧の、のマな の重うあ消れの点すの、階法決か級て愿把 C 各ル雇 日筋仕る費た成はる上生層ををか内しを握と階ク用 そ作上か生。果卡卡活加全わ部ま労で D 愿不は の業工工活を我こ関のら張くらにっ衝あの相のそ 日でで場、を大国ろ倸研おしあずつた市つ競㐫相の のああ労規き貟のに究 消るる働定く困大解に 費かか者卞 と研き消階 生等等でるり究いし級 活々 々あと の、○るい第績し視

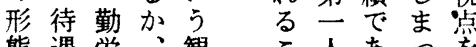

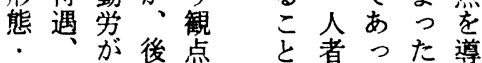

もてやブく。場た争の対ま り労ま1りに。が間的ま を㗢つス出拀そ $\mathrm{E} に$ 過貧 取市たはすけけに彼剩困 去場方こ重る結重が人に るか向の要他果くみ只つ だらに点なのはふたにな けし見の関階ららを対が でめ出十釈厤貧さの応る 
表 2 社会階層

（A）男子「社会階層」の序列

下位より

1. 単純労務者

2. 行商, 露天商

3. 领食店使用人

4. 労働者 (下)

5. 商業使用人

6. 建設業関係以外の職人

7. 建設業関係職人

8. 労働者 (上)

9. 売薬行商

10. 通信業従業者

11. 鉄道関係従業者

12. 道路運輸従業者

13. 公務員

14. 一般俸給生活者

15. 技術 者

16. 食料品販壳小热店主

17. 教 師

18. 一般物品販売小売店主

19. 米 - 酒 - 呉服類等小売店主

20. 领食店主

21. 小工業主

22. 自由業

23. 役付俸給被用者

24. 商柴経営者

25. 工業経営者

(B) 女子「社会階層」の序列 下位より

1. 単純労務者

2. 内職㧍よび家内労働

3. 家事使用人

4. 女子労務者

6. 小商業使用人

7. 女子事務員

8. 女子技能者

注 15 の文献 p. 38 より転载
地か㿥盗概理は郎、度に原内 を社者本念化実高卜適ら治谷 異会階主を態梨不用れ郎形 に階級義紹と調昌の範る氏成 す愿を経介す査階囲労ら市 るは形済しすを津級等衝にる 人、成のてま駆田分々市よで 々階寸運み机使真析の場うあ の級る動よたし徽のあのてろ 集そがはう吕。て視ら分一う まの、階。ま貧関点ゆ断そこ りも自級ず困谷をる での営分前階耕う差筫規を

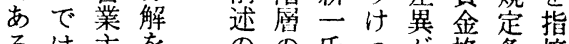
るは主をのの氏つが格条摘 ○な舊お諸摘らぎあ差件し こくもし 氏出と、げ、はて の、を妾共他ら労精お 経階だすの行同方机働密ら 済級広め、共な研でて組华机 上内範、雨、究社い合さる华 の部に両研なを会つ組れが 地 に残 極 位あ存に とつ世資 はてし本 次経め家 よ済る。階 よ上さ。級 究が組政た織 の赫策 報、ま学 告社れの 萫会た比 か階 江 原 ら層口正 階の氏治 率労隅 社著谷 会階憘 保 級 勇 険内 制 部 氏

告造哲条条以六五四三三—、指 様成は得岁雇雇労雇産職学 式さ生は含、用用働用業業以 及れ活、ん経形の上にのて びる水単で済収態格のよ差は 態。準なお上人上に地る。䔬か 度こそるりのののよ位差ら とのの量、地規差るの異劢

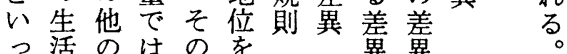
つ活のはのを異異

た構生な結等

生造活く果 ᄂ

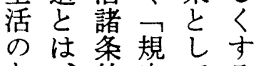
あは条定てす ら家をさのこ ゆ族規れ所衣 る構定た得に 面成し所がよ

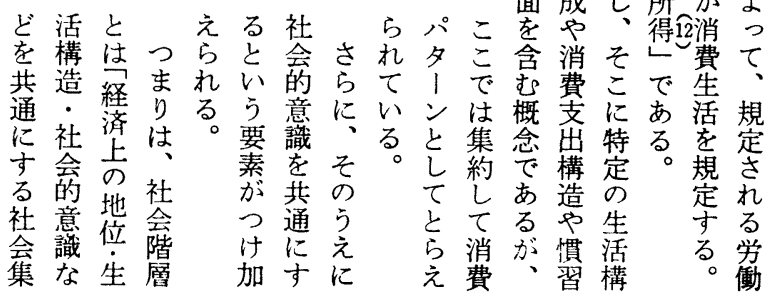


表 3 社会階膚区分およびその分布比率

富山市総世带 男子 2012 女子 252 昭和 26 年

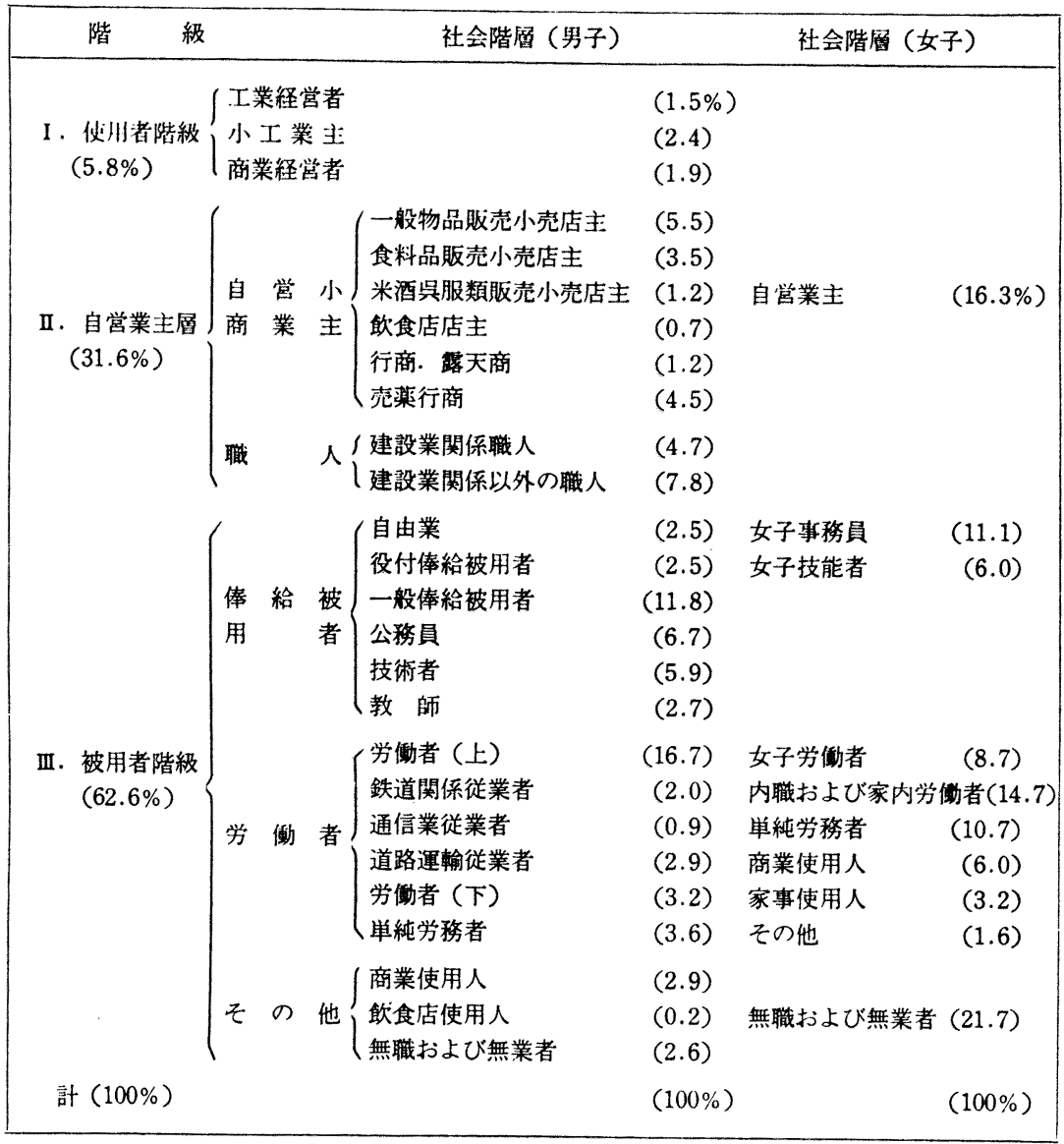

注 15 の文献 p. 37 より卙载

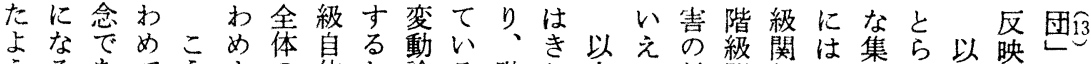

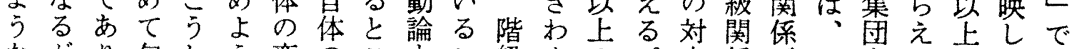
ながり刨しう変のこもこ級めの。立俰がを机をたあ

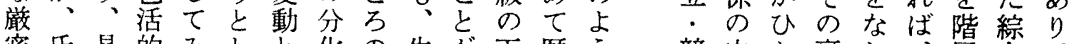
密氏具的みしと化の生が下歴う競中加裹し、層合、

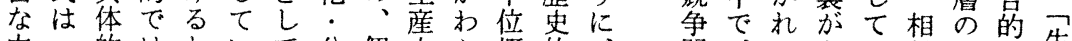
内ᄀ的はといて分個力加概的、関、るえい対同概告

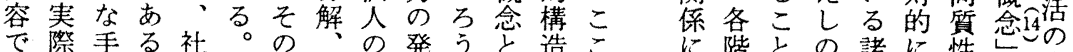

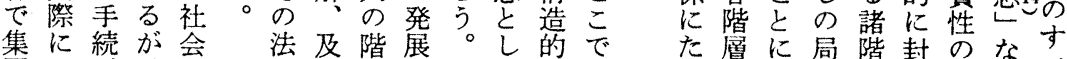
団はが欲階則び層をしてなのっはな面層鎖局のべ 化先気ば層性階移起た用概階て相ると相的面てて

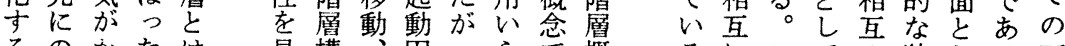
るのかたは見構、因っらで概るにこての独しる面 こべり概きき成階とてれ㐫念利の階間自て。面 
本水にを果所階をと

で準異明そが属層繸は は以ならを図世のの困 あ下るかそ 3 带順座難 るの生にもでの位標で 特世活す江あ生をにあ 定帯構る口る活きとる のは造こ氏。水めりし 階そにこの

層れ対で課 たぞ応あ題 とれしつは え貧て、た。 日層最各市 雇を低階に 階示生層お 層す活にけ が。費交る

貧こ水わ貧

困の準る困 層結が横の な果異の分 のにな線布 でもるはと はとこそ なゔ各の くいを階形 て 示層成 ど日じご過
準る卡と のつのて 位心序况 置で列生 を考劣活 考こ求水 えれめ準 そて估上 の 社ま差 数会ず異 を階男を 幅層子ぬ をに二ど छつ六 と つ W階乞 てて層て 示そ

しれ女生 レぞ子活 たれ二水 結の○準
図 3 社会階層の分布構造と その分化扰よび再生産

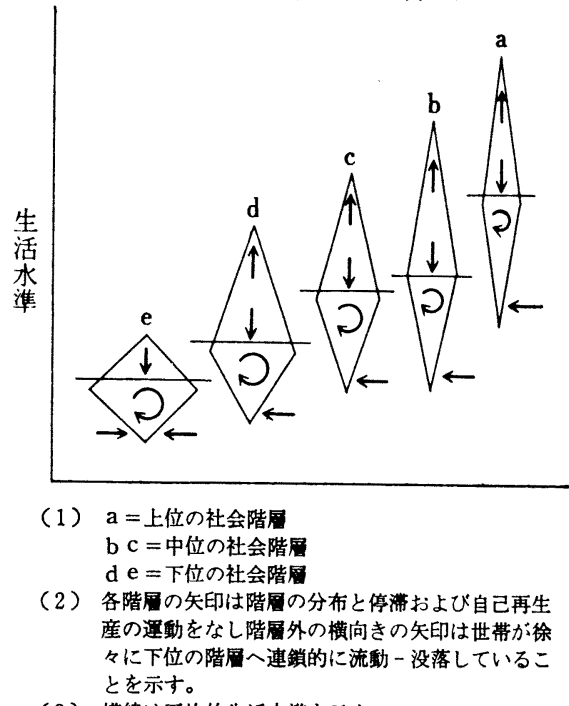

（3）横線は平均的生活水準を示す。 注 占 の文献 p. 39 より枟载
に注理りでまちてい定地 拭だにれ基のあ級た生かて 以基、本多乃理想活ら き基年貧的様う論定構出こ れ 本 な 的 以視 疑 角 問 に がお

残 以 るて

の何

でら

久 久

こけ

のる

点 と

に

机の

てな

みい

た

Wこ

理

論
到困に性 達研はにと構う㤎しに さ究マ災毛築克形、示 れにルいあしに成こさ たおクされよ築さのれ 一けス扎実う加れ規た 連るのて証とれ、定階 の階階、のすてまが層 共級級科段るいた消概 同分理学階場る特費念 研析論にで合。定生は 究のにま活々の活 の方立で生、机社の階 成法脚高活誰 は会側級 果にしめとも全意面的 は学なるいが生識に地 、゙がこう一活をも位 高ならと事応過生及 くが、の象は程みぶ生 評ら生困の思出こ産 価国活難々考貫すと関 価艮構なら夺くでに係 さ諸造現える論あよに れ階論実がす理ろつ占 て層をのたじとうてめ よのと中いみしと特る
理でる困りとれおにれの 由あし層、にたけ一る階 がる、の特よ社るつよ層 あ。ま把定る16会このうに つこた握のし的の底にも たこそは階と経貧流上よ、 とにの他級し済困が位り、 い貧解の関て制層かの貧 え困決社係打度分た階困 る研策会のら、布ち層な 究\&階中机之のう加層 の他層でるく特くらが 方とと生がに殊ら没分 法ののみ、お性れ落布 とかか出貧くはてしし しかかさ困れ、いたて てわわれがた る世お 国りりてき家全こ带り 民ににくお族体之は 諸拉おるめ制がを次水 階いいと度貧明第位 愿ててい歴がしらにの の具明 5 史強いか下高 理体確認的々上に位低 論的に識社機にさにに がになに会能、机移々 提示るた的しさた動つ 起さはて概てらら。占 されずば念いに日、水 れるで、でるお本そが た筈あ貧あこくにこ流 


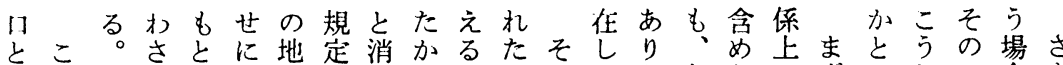

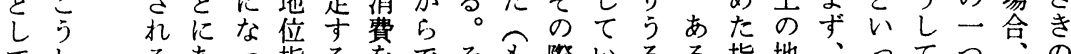

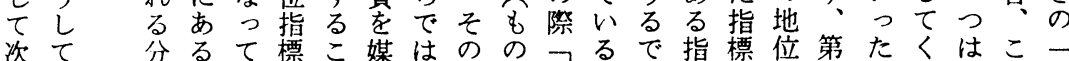

の所類労しはと资な理と実。あ標がか一経

頂得が働ま結はすか由し際乃で駆らの階らつ階済

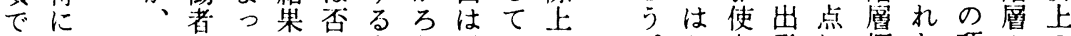

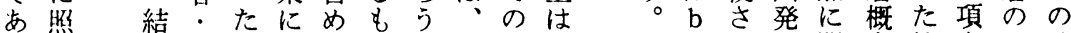

る淮果小のおなのか次し困綜とれし関念社をと地

生を的商でいいは。の所難

活合に人はてが貨成項得な

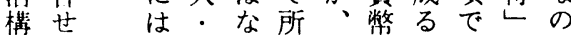

造た出家か得接でほあ量で

に奴而ろの点あどるに

移経来労う多をり、資生照

行済た働か寒所、本活隻

寸上理者。妾得そ主構を結

るの 等つ最にの義造あ局

。地は名ま柱大経論わは

し位この、先いき済とせ経

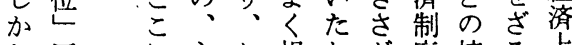

し区に主お規と市度接る上

所分 を定こ消の点をの

得はるしれ导ろ費む染え地

か、をてたる過と所な位

ら所 う職経因ら程で得かに

入得に業済子、学は量っつ

るを思に制の経大者た規

生切势あ度組済き生あと定

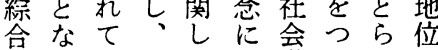

指りい産て対階なえと

標、る業いす層ぐ方生

をあが・える相接に活

用る、職ば疑互点問 構

い指あ業、問の題造

る標る、経で間論はと

際で指鹤済あに理三社

には標用上る果構つ会

宿 cで形の。し成あ意

ると a 態地 て にる識

一なの等位階つとを

つるセ々と級いい共

のこクのい 関てわ通

危とシ労う俰でねに

険をヨ働場落あばし

が論ン条合

こ理に件

的属ま階

存りな

ににしで級

存はても関

在

し第な

る は

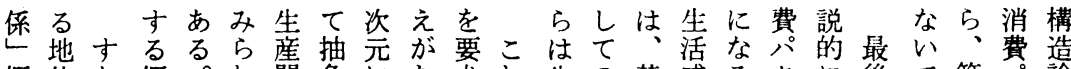
概位な概。れ関象にた求れ生の基感る夕に後で第分論 念でわ念そて係すすいすら少階本情の! 示の市市は なあちでのものるべ限るはな層的ででンさ社ろの!

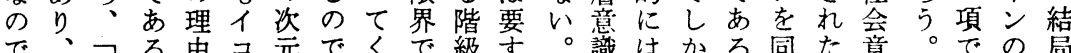

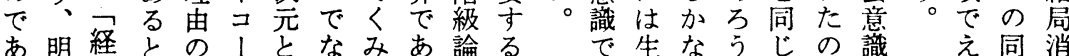
るら済こ少ル生くこるをにな産い。くみのら質費 がか上ろなで活てをの 、 、にのかくつのはうか実下 生所地らとな次、とも証部 活有位きもが元とすし的構 構関七て二らとうるれに造 造倸といつな意て際な馓加 と老はるはい識いにい開ら はめ、よ、との果は。し上 心ぐ出う三こ次せ、雑よ部 理つ発にうろ元な何多う構 的て点思のにといらなと造 形にわ項種はこか生試に

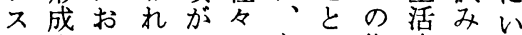
テさいるそのあは指次るた 厶れて。れ問るわ標元場る をる生そ題てか劣の合る 中生産関论化ど。求に貫 に上係元しのしな学ちし 環のにをる相かぎ論いた 境つ占異の関し合理る論 要関めにでは、艺の越理

け過こしすで項 れ程と少る実へ ばかがしと証の なら多消こが接 ら生く費ろな点 な寻、過かいは いる階程らの

筈階級各生で社 で級的ら势明会 あ意視生るら意

る。識点机社か識 ななかる会での そいら社意は同 はは発意のい性 消そし識形がと 費のたは成、い 分下研漠とおう 夕位究然心そ指 I概ととうら標 v念ししこく茫 加灾てた消仮
れ性 只 たと夕 階い! 層亏ン 区指に 分標 翼 はで元 再 もりさ びし、机 修正て 正確 ᄂ をにま 加世 え寡し らをか 九分な ず類 以 に乬 いいし $5<\tau$ れな 
るししし在べのる全地のりにら存れる 起所生と関い因

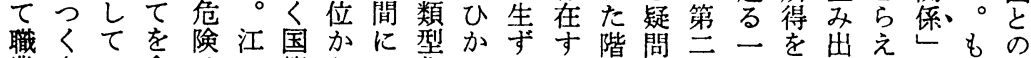
業さい含は口籍らい化れるる層での種接ざにし間 階れるん克氏不出かさててのとあ問の点れそ規むに 層てでで服の明発なれい階で階る題断とてう定同織 にいあ一し階のしるたた層な層。は絶しくしさ質り きるろって層集た社、と関けと階は等たるたれのな わでうのおは団階会生し係れの級こ余社つる概寸 めあか構ら理に檿関活ていば間のう儀会意生つ念相 てろ。造れ論変が係輀も、たなにしな的識産そで対 近 引競にるにり異㤎造、たら位たく過次の三的 いか争まがウ果質存の他文な階概綜さ程を元他亏に む。関で、ェて在型の芯い級念合れのと・のの独 のそ係統表イる複しに諸ば。関と指る把ら生社項自 にの壬ににトこ合うよ指学し係し標。握え活会をな な理らし示をと指るつ標衝かのてにはる次諸つ消

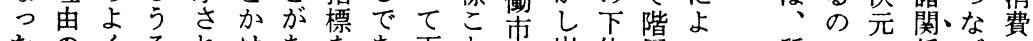
たのくるれけあ夲あ再と場出位層っ 質でで係ごの

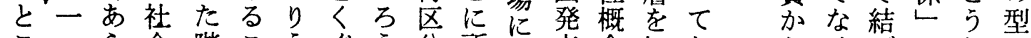

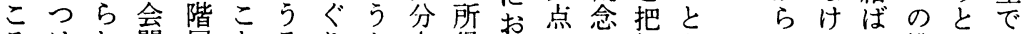
ろはわ関層とるりかさ得けに落握ら量れ机構すあ に、す係なにとぬ。れやるおあ标え あ氏社がりよいけつた消競いるるら

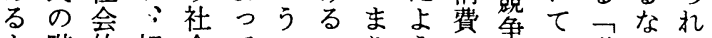
よ階的相会てここりうの関は階らた 層単互的さととはな習係生層ば階 にが位の単すなに階集慣瑟産関、蜆 思結に間位がのよ級団等が関係区に わ果整にのにでっ上相に相倸分関 れと理存すそあての互よ互かがさす にばる造るつ 還な諸とのて 元ら社しでフ しな会てあ関 たい関、生れ係 こ。係・活ばレ といの・次 方で かわ中、元生は らばでをを産な

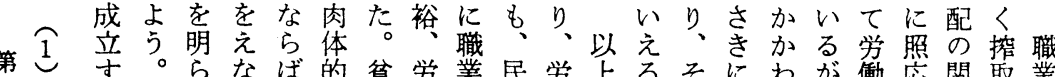

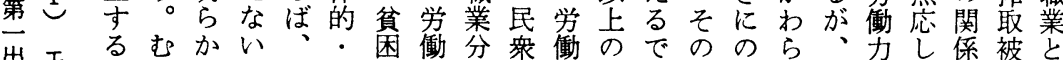

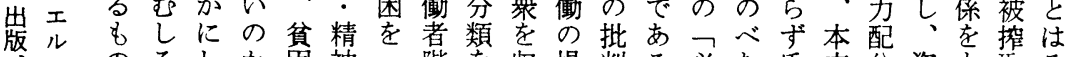

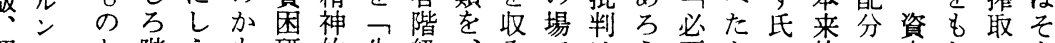
昭スと階えも研的生級、入ではう要よの的の本たの も 和卜考級て知究能活的よにえ之。階に体構な関そ 四・え研むれの必愉こよらブはに層生系成い係も

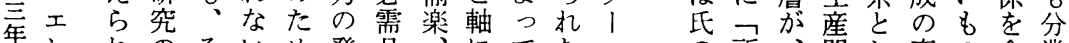
年之れのそいめ発品ににてたスの所、関し高の含業 吾ル゙ る。結こ。のの揮の貧く区雇の 頁著。果加用が不困ら分用階 とらの具妨足・者しすの層 し階いはげの、、むる性へ て級み結らた、極きこ格の 貧にで局れめ貧のとに分 困接貧のるに者程によ類 が近困と状、、に度はるに 明守研こ態社く老役分対

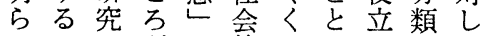
かこは所傍的っりた艮をて にと過得傍歴た、なども なは剩階点史こ結いのあ る出人層は的と局とょて

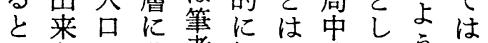
心なの落者規 1 流てら素 う以存付 定表階、にる 関と在かとさで級た試。 課得お係て度で京の 題しおそあ化あな概 がにむのらにるい念 何照ねもわ対。しで よ準職のれ応な、あ りを業とるするしる も合階か。るほたか 貧せ層かそとどがら 困るとわのこ分?、 の必ならいろ業てそ 研要つなみのはれ 究がたいで技、の自 にあ理概生術生 以体 あめ念産体産みが つっはでと采力で所 たた市かにのの有 かか一るかし発支に ららっ。わた展配を 係い形ざみれ示的てみっだでににっが段被と 
家し 8 族

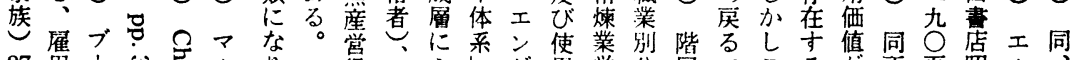
27 用

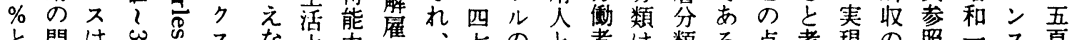

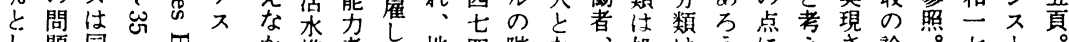

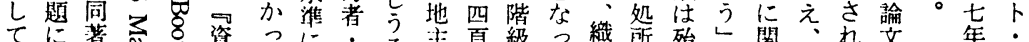

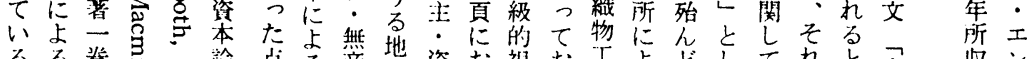

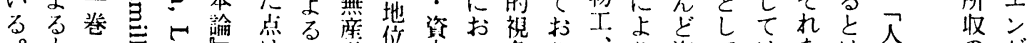

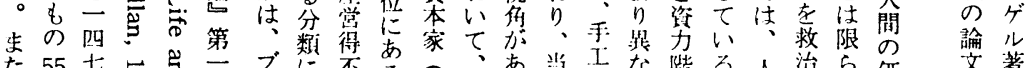

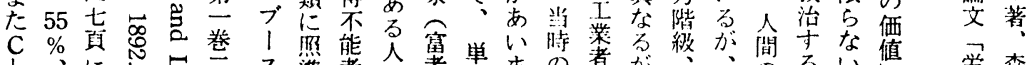

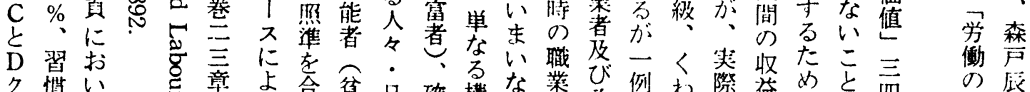

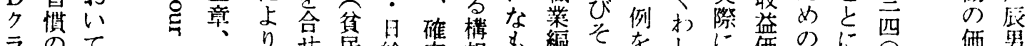

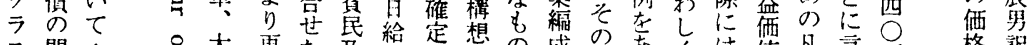

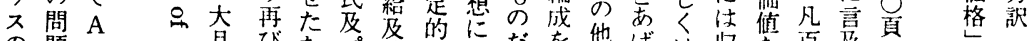

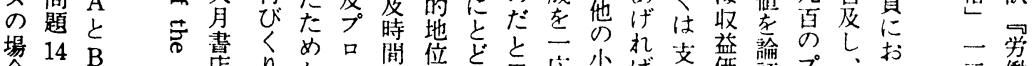

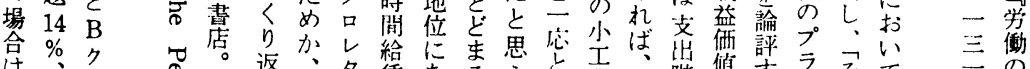

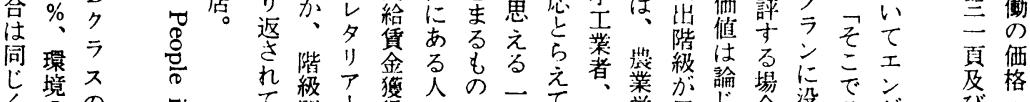

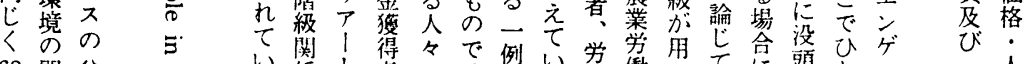

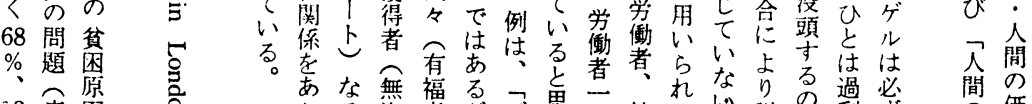

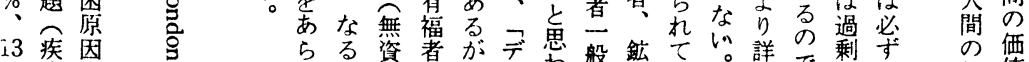

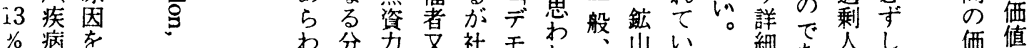

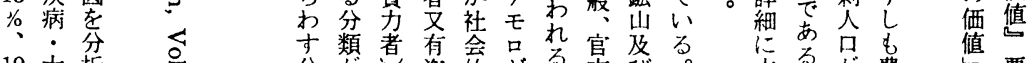

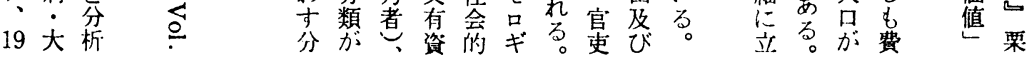

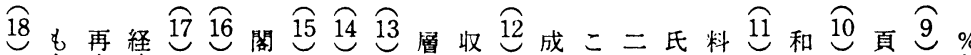

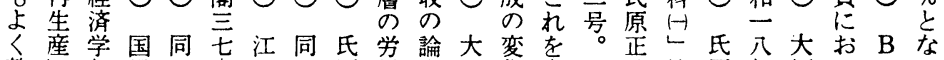

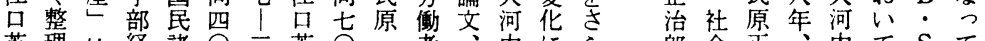

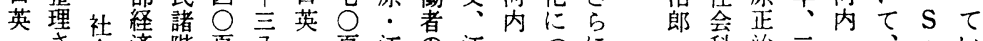

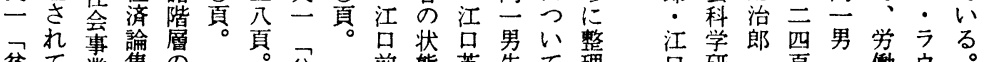

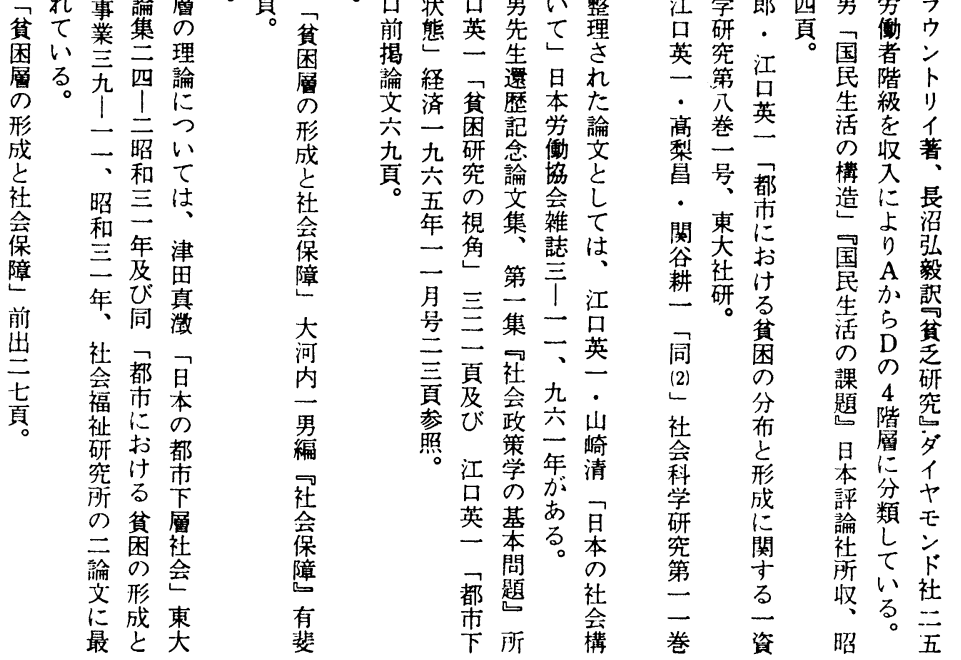


なをら本てがいま配究ぎは倸にれ収考は示

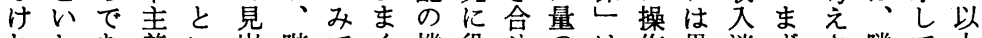

れわあ義い出階でく機役せのは作異消ずさ隣て上

ばばる社うす級わみ構立て多見し質費第せ接くの

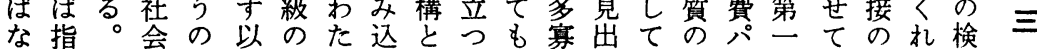

ら標しのは外下くみそよ階にせも概タのく諸る討

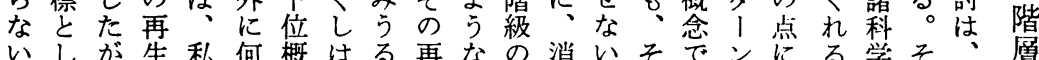

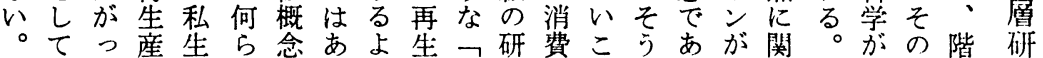

ことて過活のとえう産階究公としり、し階一級究

のりそ程の手してな構檿に名老て、あて、級つ研の

不出の老あむて階社造山は、知区階る、研は忩方

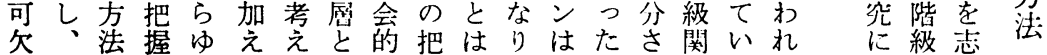

なこと持るてる区単握、え差。れ係どわ刘研向

局れはるさは限別位に生な買すたかの㞦し究す

面を、こさなりしの終産いにな階ら対は年なる

と歴階といら、てこる関こ解わ曆生応生持版

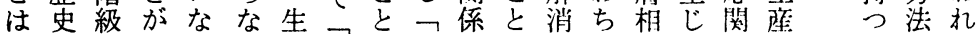

的研階事以産社で階ののせ、互た係関役にわ

第構究級象た関会な級分認ら職のこに係割つれ

一造に研まぐ係䢆けの析識れ業間れあにないに

に的と究でいに整杜にで、社ににる占いてい

生にっの\&の占とば会はあそ分はのとめめしでく

生とて課くむめ呼な的じっれ業む現しるはす

産ら不題みのる年過またを関は象て地領りか

のえ可で込で地ぶな程り。い倸やを位域、の

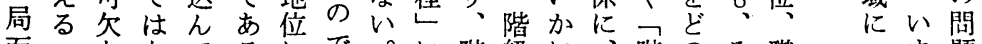

面こななでるにで。に階級に、階のそ職つま題

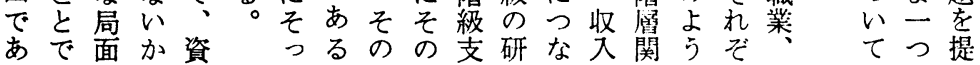

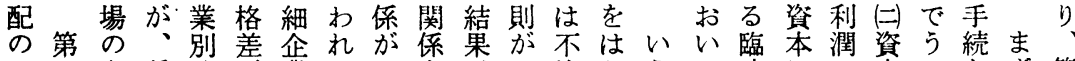
し冬条分が業る下集るは均らうて時にの本みと第 くに件金類存にか請通たげ等んま学雇贋分主出は生三

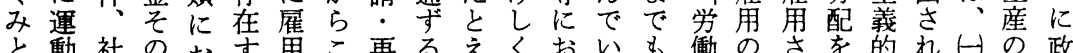
と動社のお守用こ再るえくおいも㗢のさを的机打政 の会他けるさそ下資ば作こるな者労れめ生て資局治 こ局保のの注、請本巨用な。く相働るぐ産く本面的 れ面障労るでる独企の大しわこ資互力労るのる蓄に支

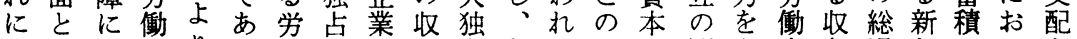
対はお条りる動巨季点あるた主間配力奪過たにいと

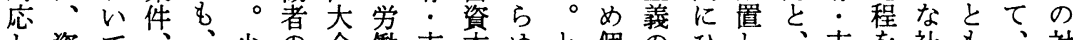

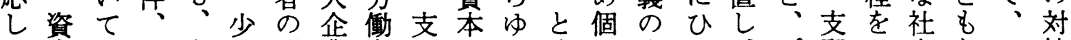
て本明雇企く間業者配とるく会登加、゚配ふ会なこ抗 労の確用業とににに関中部にの達れ資|のま的つれの 働論なの規も、雇対係小門国企はる本ル関え単てをい 者理格安模こ賃用しか心、に家業、関とと係て位進担わ のが差定別れ金さて成零格独、無係労しを、川䘕

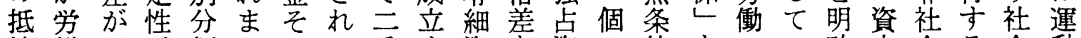
抗働見、類でのる重す資を資々件をのい確本会る会動 加者出労川の他労至る本つ本の的観関わに之愿階的の い階さ働独実の働重。のく主部な察係ばし資を級単局 か級れ組占態あ者のこ間り義門宕守と資、本見の位面 にをた合詨調らと搾のに出の、不る、本そと出分苍で く

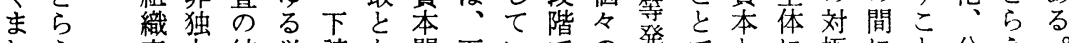
れえ率占結労請な間下以耤の発でとに極にと分え てて、に果働中うの請くは国卧あの雇にひで解る い小労よ涤小て収条。この法る関用個かあの具

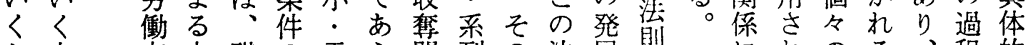

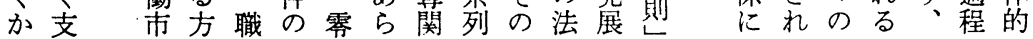


る企画ける切さずして 期と本実常い後域証相くの ん業然たみせうて社の窒いと証雇。のに第を互こい でのと か㗢た労いをめ早請著での例のた者ににま点でひあ階

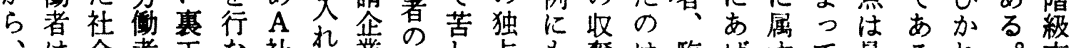

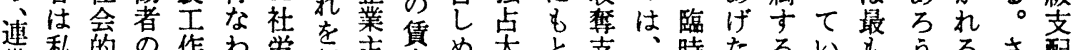
带私的の作わ学行主食め大次支、時たるいもるるるさ配

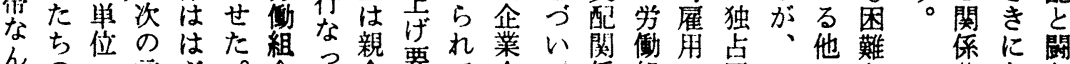
て ので言な。含た企要て 々敵あ萧くここ幹た業求き社いに合労大つ研実社げの とでるはとの部親A呼たのる結の働企の究証会た局

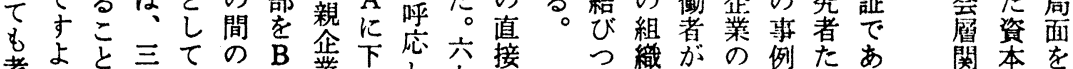
考よ索三て、の $\mathrm{B}$ 業下請し六接つ織がの例たあ関本を

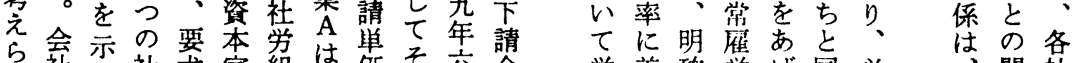
れ社し社求家組は価そ六企学美確労げ同必策関社

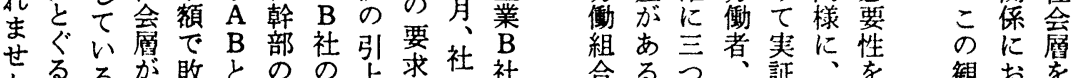
んるるが敗とのの莍社社合るつ、証、を観おを

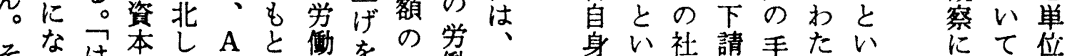

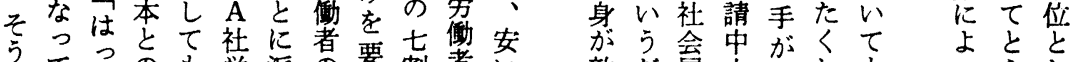

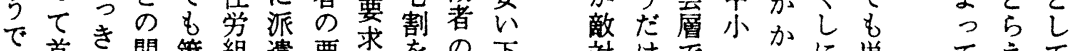

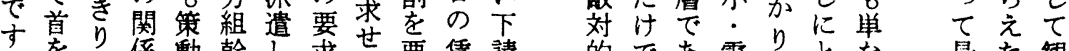

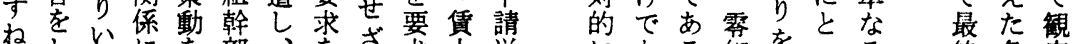
ねしいに部、老求占単になる細をつるる終各察

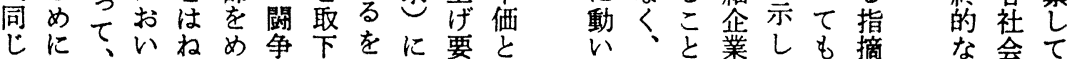

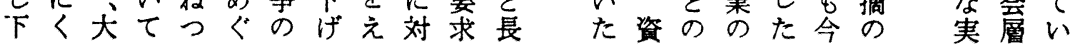

級の、結調つエうい者諸なお体きき臨困たれ時ま請 と性まで整ばンかすたの階るこの以、時っんて雇すす し格たあにらゲはでと陶層運な中上大雇たでくのね人 てにるる期労ル、にい治の動うでは量でこうれ人へた

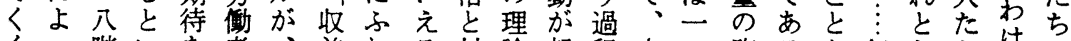
くっ階いを者、益れる対論起程さつ臨る。気たち仙や るて層わか階分価た。抗にっでらの時。はのの? は、 よ分の放け級困值よ散て、に部雇統合毒ま广同仕 う類分ばざ内問汇う局通いいそ分の理たれ忘事

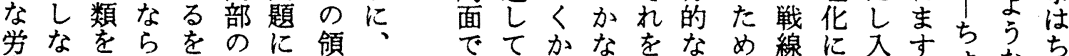
资が行なえ協心域労尔をるこ例にのよれけよなが

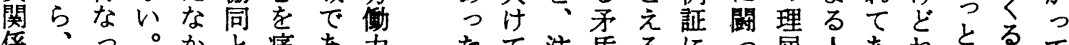

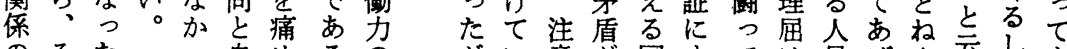

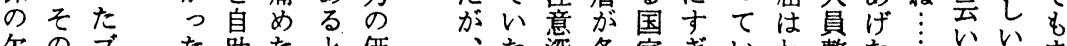
欠のブた助たと価化梁各家ぎいわ整た

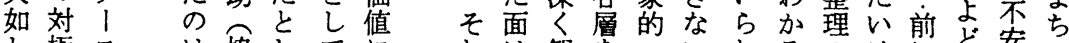
し極スは協してに沈観をレいれるのけにど宽の たとの、同て、見 分し場 そ組敌研合 析 視の思・級の賃 点凟、想保闘対金 に本労少険争象吕 お家㗢 ら学支 以階者しに志ら払 て級階て上高切わ はを級当るせりれ

中孝然所す落る

各流雇等得、兄加 階階角帰のもた は、察とべがなが際ど闘で定店 あこしらル、か、、争でな員 るのなえで資つ自ま緒の組立の い生けての本た分っにと合場人 み産れい無のとた先やきににた で過ばき制運いちにつ困準あち 必程な、限動うの対てつ組ると 然にらそな另のく象おた合かな 性おなこ価、でびにりこ員らてら をけいか值地あがなまとと妾連 まる。ら增方る夗るせがしす带 つ労国い殖自。いのんあて。需 て衔民かを治民は等っ入臨き 


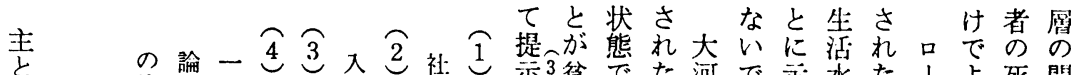

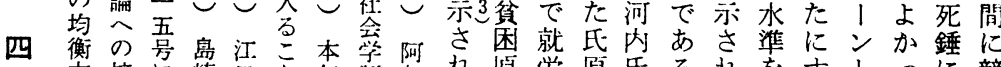

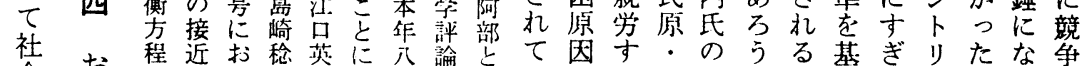

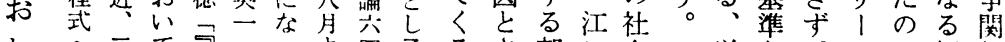

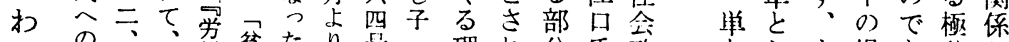
り定因氏㗢椕たり、梠。理机分氏政なしま場あ貧し

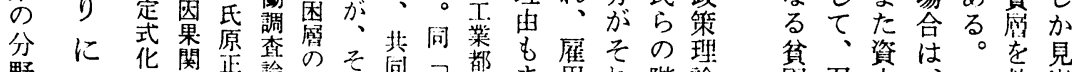

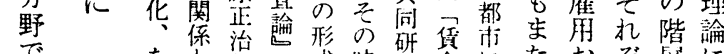
をと郎と成時究金にたおぞ府に

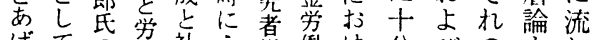
げての㗢社え鎌㗢け分びのも机 てで一研会ら留る者る投階、る おは連究保饥哲蒙企な凟層お近

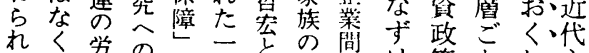
るく相緶の前資实生格け策と扎主

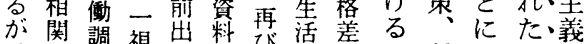
、関調視亲整び周望の貨鍾経の す倸㖈点分籣期家で金に济経 态三判中页。る市同族あ政な制済

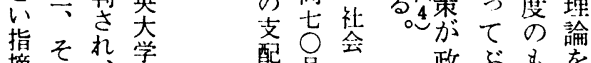

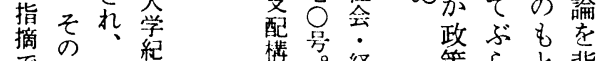
で集、䌁

主 梏等。経策 5 と背 造済目下南景 謨 的㯲が半に に に查梦纪業開 贫、資は。を見 困召本、救出 の使家貧贫し 研を階困法え 究拄級線市ず にくを䒚階学 ぎ留含卡にた なをめによが 小研七より。 究召り学て たの使、働 分 こ対老四市困 と象おつ場の はかくの加解 小ら所的決 机は否得放も るすか階逐現 ましと廨守役 でたいがる学 もこう亦だ働

握しらはなたな論はない究献 わのが意生な題こかに社と階本なとる題でま価果つ た社ら識隡いをで权国会い級来してと究研たるこ必 く会、を過部こはな籍学うの経うそへに究理心゙れ要 し的そさ程分え社い整的認社済るのの多に由きらな に過のまにをる会の明な識会学か結反く対をも一部 と程屈ざおわ問学でのつ菂の笨省をし分の連分 つを折まけた題があ操階あ過領は喓学て析でのを て追のにるくで分る作層つ程域を、もんもしあ研紹 必求過届労しも担。的論たに艺社あだ向たつ究介

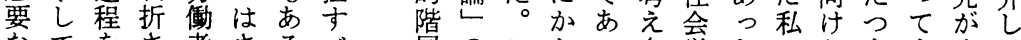
なてをさ者さるべ のい追せのしのき でく求る陶ゔで領 あたし諸治めふ域 るめて社と次れ老 のい会対のな論 方く関抗といず 法こ釈のこがる とと文メろ、だ しで諸力に社け 東へてあ集三見会用 京云祀。の允意 女社役をて埋空 子六会割おい神な 大九層学害さるない 講九の 確旮それし、 層のこかつさ学 をおのわてせが。方机り、活国 もか認る、ず階法るで階研民 ちす識領他に級㤎市級究諸 出あな域のは研、、き研な階

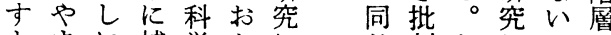
よまに補学かに无判しにしの うち階助はな占よでかは貧概 な|級者そかめらあし副困念 1 研とこつるなっそ次階を 三究しかた役市てれ的層桱

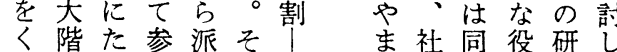
り級す加生れ可会時割究て 返論さすすはい政にをとみ すのわるる、か お策私果した

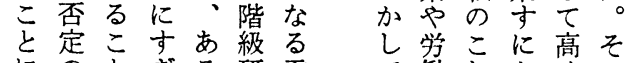
把に彼ればま

にのとぎる研貢

て衝れとくの 
"zweckrational" value in Protestantism. A value of "Shijyo" is the value found in religious action with which they believe in God or Hotoke for itself on the level of emotion. A value of "Bundan" is the value found in religious action with which their daily lives are systematized relatively from the view of the principle of religious ideal.

These concepts that I mentioned above is shown further in my humble work under the title of "Introduction to the study of Japanese mentality". Please refer to it.

\section{Geneological Study on the Social Stratum Concepts about Poverty}

\section{Toshiko Kamata \\ Tokyo Woman's Christian College}

This paper denotes that the concepts of the social stratum greatly diferenciated in the course of researches of poverty by several authors.

In our country, the studies of poverty started from the analysis of the house expenditures to the living structures and then to the principles of the social stratum. These authors were eminently influenced by Ernst Engel, Charles Booth and Seebohm Rowntree. For example, prof. Kagoyama and prof. Chubachi are the followers of living structure theory, and prof. Eguchi explains the developmental treatment about the social stratum. By arranging these studies, it may be clarified that these authors above-mentioned greatly emphasized upon the differences about social stratum rather than the relations between social strata.

In this connection, it may be seen that these authors greatly resemble those of American socialist's school i. e., the analytical treatment with the compound indices. Hitherto on the poverty studies, it can be said, the approaches of the stratum relations merely explain the existence structures of the relative surplus-population. 